Научная статья

УДК 599:571.54

DOI: $10.18101 / 2542-0623-2021-4-7-44$

\title{
МЛЕКОПИТАЮЩИЕ БУРЯТИИ: ТАКСОНОМИЧЕСКИЙ СОСТАВ И ТЕРРИТОРИАЛЬНОЕ РАЗМЕЩЕНИЕ
}

\section{Ц. З. Доржиев}

\section{(C) Доржиев Цыдыпжап Заятуевич}

доктор биологических наук, профессор,

Бурятский государственный университет имени Доржи Банзарова

Россия, 670000, г. Улан-Удэ, ул. Смолина, 24а

Институт общей и экспериментальной биологии СО РАН

Россия, 670047, г. Улан-Удэ, ул. Сахьяновой, 6

tsydypdor@mail.ru

Аннотация. На основе литературных и собственных данных приведен обновленный аннотированный список млекопитающих Бурятии, зарегистрированных на территории республики в последние 50 лет. Виды, отмеченные до 70-х гг. прошлого столетия и исчевнувшие потом (заяц-русак Lepus europaeus, енотовидная собака Nyctereutes procyonioides, пятнистый олень Cervus nippon, дзерен Procapra gutturosa), не вошли в список. Исключены также виды из сопредельных территорий, которые явно не обитают в республике. Потерпели заметные изменения состав отрядов рукокрылых и грызунов в связи с пересмотром их систематики. В результате видовой состав млекопитающих Бурятии увеличился более чем на 10 видов по сравнению с предыдущими данными. В настоящее время териофауна республики насчитывает 93 вида, относящихся к 6 отрядам, 21 семейству и 57 родам. Отряд Eulipotyphla насекомоядных включает 12 видов, Chiroptera рукокрылых - 11, Lagomorpha зайцеобразных - 5, Rodentia грызунов - 35, Carnivora хищных - 19 и Artiodactyla парнокопытных - 7. Названия видов даны по новым сводкам, но во избежание путаницы приведены еще прежние названия. Описаны особенности ареалов всех видов, характер распространения и биотопического распределения их по Бурятии. Уточнены и указаны новые места находок некоторых форм на территории республики. Показана значительная доля $(44,1 \%)$ видов, находящихся на границе ареалов в Бурятии. Кроме того, отмечено два эндемичных вида - муйская полевка и байкальская нерпа. Для рукокрылых указаны характер пребывания и места зимовок.

Ключевые слова: млекопитающие, таксономический состав, ареал, биотопическое размещение, Бурятия, Байкальский регион.

Благодарности. Работа выполнена при частичной финансовой поддержке гранта инновационных научных исследований Бурятского государственного университета в 2021 г. (№ 21-06-0502).

\section{Для цитирования}

Доржиев Ц. 3. Млекопитающие Бурятии: таксономический состав и территориальное размещение // Природа Внутренней Азии. Nature of Inner Asia. 2021. № 4(19). С. 7-44 DOI: $10.18101 / 2542-0623-2021-4-7-44$ 


\section{Введение}

Млекопитающим Байкальского региона, включая территорию Бурятии и отдельных ее районов, посвящен ряд работ, в том числе монографии и обзорные статьи [Реймерс, 1966; Матурова, Доржиев, Иванова, 1977; Скалон, Шаргаев, 1977; Швецов, 1977; Юдин, Галкина, Потапкина, 1979; Литвинов, 1982; Матурова, 1982; Швецов, Смирнов, Монахов, 1984; Доржиев, Хабаева, Юмов, 1986; Юдин, 1973, 1989; Лямкин, 1977, 1983, 1986, 2001, 2002; Борисова и др., 2001; Ботвинкин, 2002; Попов, 2009; Попов, Гулгонов, Китаев, 2017; и др.]. В последнее время пересмотрен таксономический статус многих групп и форм млекопитающих, изменились их названия [Млекопитающие России... 2012]. Появились новые виды и свежие данные по распространению. Поэтому возникла необходимость приведения в соответствие систематического состава териофауны Бурятии.

Цель настоящей работы - составить обновленный таксономический список млекопитающих Республики Бурятия с учетом появившихся изменений и новых сведений и показать особенности географического и биотопического распределения каждого вида.

\section{Материал и методика}

Таксономический список млекопитающих Бурятии составлен на основании анализа литературных и собственных данных. Для каждого вида приведены следующие характеристики: название (для отдельных видов дополнительно указаны с оговоркой «старые» названия и синонимы), ареал, распространение на территории Бурятии, биотопическое размещение. Выделены виды, находящиеся на периферии ареалов. Особенности распространения некоторых слабо изученных видов даны более подробно с подтверждением конкретных мест находок. При описании характера распространения использовали физико-географические названия территорий, в отдельных случаях для лучшей ориентировки привязку осуществляли к административным районам и населенным пунктам.

Порядок и названия таксонов даны по книге «Млекопитающие России: Систематико-географический справочник» [Павлинов, Лисовский, 2012]. В некоторых случаях русские названия приведены по сводке «Млекопитающие России: список видов и прикладные аспекты» [Лисовский и др., 2019].

\section{Краткое описание района исследований}

Республика Бурятия (далее Бурятия) расположена на юге Восточной Сибири в пределах двух крупных физико-географических стран Алтае-Саянской горной и Байкальской горной страны, составляющих вместе природный регион горы Южной Сибири. Алтае-Саянская горная страна в Бурятии представлена восточной частью Восточного Саяна (Окинский и Тункинский районы). Байкальская горная страна - большей частью Прибайкалья (Восточное Прибайкалье), Западным Забайкальем (Селенгинское среднегорье, Джидинский горный район и Витимское плоскогорье) и южной частью Станового нагорья (рис.). Селенгинское среднегорье и Джидинский горный район иногда приведены под названием Селенгинское Забайкалье, имея в виду их как территорию бассейна р. Селенги в пределах Российской Федерации. Бурятия разделена на 21 административных района Республики Бурятия (табл. 1).

Более подробная информация об особенностях природных условий Республики Бурятия нами приведена в другой статье [Доржиев, Бадмаева, 2016]. 


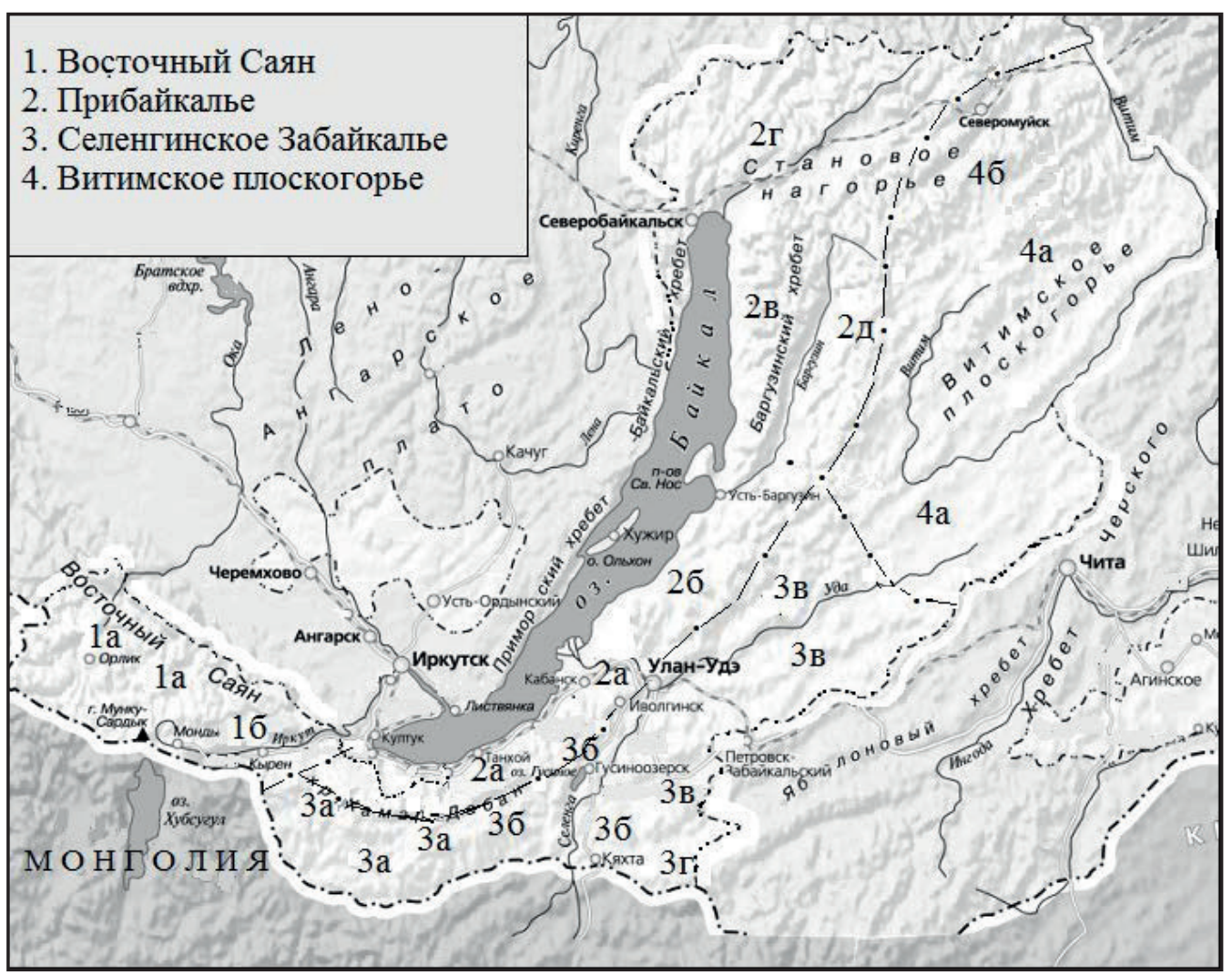

Puc. 1. Эколого-географическая карта Республики Бурятия

Обозначения: -. - — государственная граница; -.. - - границы Республики Бурятия; --. -- - границы эколого-географических округов. Эколого-географические округа и районы: 1. Восточный Саян: 1а - Окинское нагорье, 16 - Тункинская котловина; 2. Прибайкалье: $2 \mathrm{a}$ - Южное Прибайкалье, 26 - Восточное Прибайкалье, 2в - СевероВосточное Прибайкалье, 2 - - Северное Прибайкалье, 2д - Баргузинское Прибайкалье; 3. Селенгинское Забайкалье: 3a - Джидинско-Мало-Хамар-Дабанский горнотаежный район, $3 б-$ - еленгинский лесостепной район, 3в - Хилокско-Удинский район, 3г Чикойский горнотаежный район; 4. Витимское плоскогорье: $4 \mathrm{a}$ - Витимское плоскогорье; 46 - юго-восточная часть Станового нагорья (условно отнесена к Витимскому плоскогорью).

Таблииа 1

Физико-географические и административные районы Бурятии

\begin{tabular}{|c|c|c|}
\hline \multicolumn{2}{|c|}{$\begin{array}{c}\text { Физико-географические районы на } \\
\text { территории Бурятии }\end{array}$} & Административные районы Бурятии \\
\hline \multicolumn{3}{|c|}{ Алтае-Саянская горная страна } \\
\hline 1 & $\begin{array}{c}\text { Восточная часть Восточного } \\
\text { Саяна }\end{array}$ & Окинский и Тункинский \\
\hline \multicolumn{3}{|c|}{ Байкальская горная страна } \\
\hline 1 & Восточное Прибайкалье & $\begin{array}{l}\text { Кабанский, Прибайкальский, Баргузин- } \\
\text { ский, Курумканский и Северо-Байкальский } \\
\text { (нижняя часть долины р. Верхняя Ангара) }\end{array}$ \\
\hline
\end{tabular}


Продолжение табл. 1

\begin{tabular}{|c|c|l|}
\hline 2 & $\begin{array}{c}\text { Селенгинское Забайкалье } \\
\text { (Селенгинское среднегорье и } \\
\text { Джидинский горный район) }\end{array}$ & $\begin{array}{l}\text { Закаменский, Джидинский, Бичурский, } \\
\text { Мухоршибирский, Селенгинский, Тарбага- } \\
\text { тайский, Иволгинский, Заиграевский, } \\
\text { Кижингинский, Хоринский }\end{array}$ \\
\hline 3 & Витимское плоскогорье & Еравнинский, Муйский, Баунтовский \\
\hline 4 & юг Станового нагорья & $\begin{array}{l}\text { Северо-Байкальский (средняя и верхняя } \\
\text { часть бассейна р. Верхняя Ангара) }\end{array}$ \\
\hline
\end{tabular}

Результаты

\section{ОТРЯД НАСЕКОМОЯДНЫЕ - EULIPOTYPHLA \\ WADDELL, OKADA ET HASEGAWA, 1999}

\section{Подотряд Ежеобразные - Suborder Talpomorpha Bugge, 1974}

\section{Семейство Ежовые - Erinaceidae Fischer, 1814}

\section{1. Даурский еж - Hemiechinus dauuricus Sundevall, 1841}

Монгольский вид: южные районы Забайкалья, северо-восточная Монголия и северо-восточный Китай. В Бурятии вид находится на северной границе ареала. Область распространения в республике ограничена южной и центральной частью Селенгинского среднегорья (Кяхтинский, Джидинский, Селенгинский, Иволгинский, Бичурский, Мухоршибирский, Иволгинский районы). Известны единичные встречи в Тарбагатайском районе, есть сведения о находке в окр. с. Онохой (нижняя часть долины р. Уда) [Доржиев и др., 1985; Доржиев и др., 1989]. Последние, по нашим данным, являются самыми северными точками встречи даурского ежа в Бурятии. В недавней сводке по насекомоядным млекопитающим России [Зайцев, Войта, Шефтель, 2014] о северной границе написано, что она пересекает p. Селенгу в районе г. Улан-Удэ и далее проходит вдоль правого берега Уды, затем идет на северо-восток и подходит к Витиму около п. Романовка. Такое утверждение требует дополнительного изучения и уточнения. Обитатель степных и лесостепных биотопов.

\section{Подотряд Кротообразные - Suborder Talpomorpha Bugge, 1974}

\section{Семейство Кротовые - Talpidae Fischer, 1814}

\section{2. Алтайский крот - Talpa altaica Nikolsky, 1883}

Сибирский вид. В Бурятии находится на восточной границе ареала. Распространен неравномерно: Восточный Саян (Тункинский и Окинский районы) и долина р. Иркута (окр. с Кырен, устн. сообщение Л.Д. Базарова), Прибайкалье 
(Кабанский район по хр. Хамар-Дабан), Селенгинское среднегорье (Закаменский и Джидинский районы по Джидинскому хребту и Малому Хамар-Дабану, долина p. Джида). Местообитания: леса с хорошо развитым подлеском и травостоем на рыхлых и влажных почвах, субальпийские луга и высокогорная тундра [Юдин, Галкина, Потапкина, 1979], влажные луга в долинах рек хр. Малого Хамар-Дабана и долине р. Иркут.

\section{Подотряд Землеройкообразные - Suborder Soricomorpha Gregory, 1910}

\section{Семейство Землеройковые - Soricidae Fischer, 1814}

3. Манчжурская белозубка - Crocidura shantungensis Miller, 1901

Ранее рассматривалась в составе Crocidura suaveolens малой белозубки. В ранних работах по Бурятии идет под этим названием. В настоящее время они рассматриваются как самостоятельные аллопатрические виды.

Восточносибирский вид умеренного и северной части субтропического пояса. В Бурятии встречается на юге Селенгинского среднегорья. Находок немного: в Джидинском районе - низовье р. Ичеты (левый приток Джиды), окр. с. Дырестуй, в Кяхтинском районе - окр. г. Кяхты, местность Старая Капчеранка [Юдин, 1973; Швецов, Смирнов, Монахов, 1984]. Места обитания на юге Бурятии - биотопы в степных ландшафтах, находили манчжурских белозубок в осоковом лугу и ивняках пойм рек Джиды и его притока Ичеты, на поле под кладью пшеницы и смешанном лесу около Кяхты [Швецов, Смирнов, Монахов, 1984].

4. Обыкновенная кутора - Neomys fodiens Pennant, 1771

Евразийский вид с разрывом ареала: Европа (кроме Присредиземноморья), далее на восток до Енисея, Забайкалья и северной Монголии, также Казахстан, Тянь-Шань; изолированный участок в Приморье, на Сахалине, северо-восточном Китае и севере Корея [Банникова, Лебедев, 2012]. В Бурятии обитает по всем районам в околоводных лесных биотопах практических всех хребтов, предпочитает берега мелких и крупных рек, наибольшей численности достигает в биотопах с густыми кустарниковыми зарослями и хорошо развитым травянистым покровом и постилкой [Швецов, Смирнов, Монахов, 1984].

5. Обыкновенная бурозубка - Sorex araneus L., 1758

Евразийский вид бореального пояса, распространенный от Британского острова до Восточной Сибири (до Прибайкалья). В Бурятии проходит восточная граница ареала и встречается неравномерно в пределах Восточного Саяна, Прибайкалья: Баргузинский хр., п-ов Святой Нос, дельта р. Селенги, хр. ХамарДабан, Улан-Бургасы [Литвинов, Тарасов, Швецов, 1969; Юдин, 1973, 1989; Швецов, 1977; Матурова, 1982; Швецов, Смирнов, Монахов, 1984]. Населяет различные лесные биотопы и гари с умеренным увлажнением и хорошо развитым кустарниковым и травянистым покровом.

6. Тундряная бурозубка - Sorex tundrensis Merriam, 1900

В некоторых работах, касающихся территории Бурятии, идет под названием арктическая бурозубка Sorex arcticus [Швецов, 1977; Юдин, Галкина, Потапкина, 1979]. Сибирско-североамериканский вид, ареал которого охватывает 
субарктический и бореальный пояса от Урала до Дальнего Востока (Россия и северо-восточный Китай) и северо-западные части Северной Америки. В Бурятии встречается во всех районах. Населяет различные биотопы во многих ландшафтах, предпочитают пойменные луга с кустарниками из ивы, ольхи, березового ерника, захламленные пихтово-тополевые уремы. Встречается в подгольцовом и гольцовом поясе. Неохотно занимает горную темнохвойную тайгу [Литвинов, Тарасов, Швецов, 1969; Швецов, 1977; Юдин, Галкина, Потапкина, 1979; Швецов, Смирнов, Монахов, 1984].

\section{7. Крупнозубая бурозубка - Sorex daphaenodon Thomas, 1907}

Восточный палеаркт, ареал охватывает таежную зону от Урала до побережья Тихого океана. Встречается на большей части территории Бурятии за исключением Восточного Саяна. Населяет лесные биотопы, предпочитает влажные местообитания с хорошо развитой глубокой и рыхлой подстилкой, приуроченных к долинам рек, берегам озер или болотам. Менее благоприятные условия обитания находит в горной тайге [Швецов, Смирнов, Монахов, 1984; Лямкин, 2002].

\section{8. Средняя бурозубка - Sorex caecutiens Laxmann, 1788}

Восточноевропейско-азиатский вид лесной зоны умеренного пояса, распространенный от севера Восточной Европы до Тихого океана, включая северные области Монголии, Китая и Японии [Соколов, Орлов,1980; Гуреев, 1979; Юдин, 1989;]. В Бурятии встречается во всех районах. Эвритопный вид, населяет различные лесные биотопы в горных (до нижней части гольцового пояса) и равнинных ландшафтах, в безлесных местообитаниях редок, обширные открытые участки избегает [Литвинов, Тарасов, Швецов, 1969; Швецов, 1977; Юдин, Галкина, Потапкина, 1979; Матурова, 1982; Швецов, Смирнов, Монахов, 1984; Лямкин, 2002].

\section{9. Равнозубая бурозубка - Sorex isodon Turov, 1924}

Восточноевропейско-дальневосточный бореальный вид, занимающий лесную зону от Скандинавского полуострова до побережья Тихого океана, о. Сахалин, Курилы. В Бурятии встречается в лесных ландшафтах Восточного Саяна, Прибайкалья, Станового нагорья. В Селенгинском среднегорье она не отмечена. Заселяет различные типы местообитаний во всех высотных поясах. Предпочитает таежные биотопы - кедровые леса, смешанные леса с участием кедра, пихты. Обитает в подгольцовом поясе в зарослях кедрового стланника, но здесь редка [Литвинов, Тарасов, Швецов, 1969; Швецов, 1977; Юдин, Галкина, Потапкина, 1979; Матурова, 1982; Швецов, Смирнов, Монахов, 1984; Лямкин, 2002].

10. Плоскочерепная (бурая) бурозубка - Sorex roboratus Hollister, 1913

Североазиатско-дальневосточный бореальный вид (восточный палеаркт), распространен от р. Оби до Тихоокеанского побережья. В Бурятии плоскочерепная бурозубка встречается во всех районах, но более широко распространена на хребтах и долинах Прибайкалья, Станового нагорья. Населяет различные местообитания от луговых до горно-таежных, предпочитает разреженные леса с кустарниками, особенно в долинах рек, а также кустарниковые луга, лесные болота, вторичные хвойно-мелколиственные леса на террасах [Швецов, 1977; Швецов, Смирнов, Монахов, 1984; Лямкин, 2002]. 


\section{1. Крошечная бурозубка — Sorex minutissimus Zimmermann, 1780}

Восточноевропейско-дальневосточный гипоаркто-бореальный вид, ареал которого охватывает область от центральных и северных районов Восточной Европы до побережья Тихого океана, включая Чукотку, Камчатку, Сахалин и Японские острова, на юге - Северную Монголию и Северо-Восточный Китай [Долгов, 1985; Юдин, 1989]. В Бурятии встречается во всех районах. Населяет различные лесные биотопы, тяготеет к таежным, смешанным хвойно-лиственным разреженным лесам и кустарниковым зарослям с хорошо развитым травянистым покровом [Швецов, Смирнов, Монахов, 1984; Лямкин, 1988, 2002].

\section{2. Малая бурозубка - Sorex minutus Linnaeus, 1766}

Европейско-сибирский бореальный вид, изолированный участок - ТяньШань. Восточная граница ареала проходит по Прибайкалью. В Бурятии находится на восточной окраине ареала, встречается спорадично по всей республике. Населяет лесные и лесостепные биотопы, при этом явное предпочтение отдает участкам с развитым кустарниковым подлеском, зарослям кустарников с влажной почвой и лугам с хорошим травянистым покровом [Литвинов, Тарасов, Швецов, 1969; Швецов, Смирнов, Монахов, 1984; Лямкин, 2002].

ОТРЯД РУКОКРЫЛЫЕ - CHIROPTERA

BLUMMENBACH, 1779

\section{Подотряд Suborder Yangochiroptera Koopman, 1985}

\section{Семейство Гладконосые (Кожановые) - Vespertilionidae Gray, 1821}

\section{3. Большой (Сибирский) трубконос - Murina hilgendorfi Gray, 1842}

Раньше трубконосов Сибири и Дальнего Востока рассматривали в составе Murina leucogaster. Murina hilgendorfi близок к нему, но хорошо обособлен как самостоятельный вид. Согласно морфологическим и молекулярным данным, M. hilgendorfi представлен двумя подвидами [Kruskop, 2005; Kruskop et. al., 2012]. В предыдущих работах по Байкальскому региону [Борисова и др., 2001; Ботвинкин, 2002] название данного вида приводится как Murina leucogaster.

Южносибирско-восточноазиатский вид: распространен от Алтая до Сахалина и Японии, на юг до северной Монголии, северо-восточного Китая и Кореи [Крускоп, 2012]. В Байкальском регионе проходит северная граница ареала, найдены в Иркутском, Аларском, Тайшетском районах Иркутской области, где встречается крайне спорадично [Ботвинник, 2002; Попов, 2011]. В Бурятии известно несколько точек встречи сибирских трубконосов: Восточный Саян - долина рек Кыренга и Харагун, Тункинский район; Прибайкалье - p. Переёмная на Хамар-Дабане, Кабанский район; долины рек Давша и Таркулик на территории Баргузинского заповедника, Северобайкальский район; Витимское плоскогорье - п. Багдарин, пещера Долганская Яма, оз. Верхняя Джилинда, Баунтовский район [Ботвинкин, 
Осинцев, 1995; Ботвинкин и др., 2001; Ботвинкин, 2002; Казаков, 2015; Казаков и др., 2016]. Места обитания в теплые сезоны года приурочены к разреженным лесам с полянами, опушками, расположенных в горной и холмистой местности, прячутся в пещерах и тоннелях. Зимуют в пещерах, в частности, в Бурятии они найдены на зимовке в небольшом числе в пещере Долганская Яма Баунтовского района [Ботвинкин и др., 2001; Казаков и др., 2016].

14. Амурская ночница - Myotis bombinus Thomas, 1906

Ранее рассматривался в составе M. nattereri, в настоящее время признается видовая обособленность [Horaček, Hanak, 1984; Крускоп, 2012].

Восточноазиатский вид, за пределами основного ареала встречается до Восточной Сибири. В Бурятии пока известна очень давняя находка на р. Тунка (левый приток р. Иркут) в Тункинском районе (Восточный Саян) (Огнёв, 1928: по Ботвинкин, 2002). Эта самая западная точка регистрации данного вида. Восточнее Бурятии в Забайкальском крае есть еще одна давнишняя встреча на р. Тунгир, но этот факт вызывает сомнение из-за не точного указания места [Ботвинкин, 2002]. По двум встречам трудно сказать, в каких местообитаниях живет амурская ночница. На Дальнем Востоке обитает в смешанных лесах [Тиунов, 1997].

\section{5. Длиннохвостая ночница - Myotis flater G.Allen, 1923}

Южносибирско-восточноазиатский вид, ареал, которого охватывает Южную Сибирь, Приморье, Корею, Японию и среднюю часть Китая [Крускоп, 2012]. Встречается очень спорадично, в Сибири известно несколько участков ареала. В Бурятии найдены костные остатки данного вида на Витимском плоскогорье в пещере Долганская Яма (Баунтовский район) [Ботвинкин и др., 2001]. Судя по данным из других регионов, длиннохвостая ночница обитает в различных лесах, охотящихся зверьков встречали вблизи водоемов [Тиунов, 1997].

\section{6. Ночница Иконникова - Myotis ikonnikovi Ognev, 1912}

Сибирско-восточноазиатский вид, обитает на юге Средней и Восточной Сибири, Дальнего Востока, в Монголии, Северо-Восточном Китае, Корее, Японии [Круоскоп, 2012]. В Бурятии данный вид отмечен в Восточном Саяне, но места находок не указаны (Борисова и др., 2001), в разных районах Прибайкалья и Байкала: на Хамар-Дабане в долинах рек Мишиха, Снежная, Выдрино, Осиновка, с. Танхой; на Малом Хамар-Дабане - Хамней, у оз. Таглей; на хр. Улан-Бургасы - оз. Котокель; на Баргузинском хр. - долины рек Томпуда, Таксаки, Давша, Кабанья; п-ов Святой Нос и перешеек [Фетисов, 1936; Филонов, 1962; Швецов, Смирнов, Монахов, 1984; Reiter, Benda, 1995; Ботвинкин, 2002]. На Витимском плоскогорье она известна из с. Багдарин и пещеры Долганская Яма [Ботвинкин и др., 2001; Ботвинкин, 2002].

Ночница Иконникова обычно населяет горные таежные леса с развитой гидрологической сетью, встречается и в других биотопах - на открытых берегах водоемов, например, на берегу Байкала, среди смешанного леса, припойменных зарослях и т. п. [Швецов, 1977; Reiter, Benda, 1993; Ботвинкин, 2002]. Зимует в карстовых полостях, пещерах и прочих убежищах, наблюдается среди зимующих рукокрылых в пещере Долганская Яма в Баунтовском районе [Ботвинкин и др., 2001; Ботвинкин, 2002]. 


\section{7. Степная ночница - Myotis davidii Peters, 1869}

Раньше включали в группу подвидов усатой ночницы Myotis mystacinus, затем ее выделили как самостоятельный вид M. aurascens. После анализа старых типовых коллекций переименован в M. davidii [Benda et al., 2012]. В предыдущих работах по Байкальскому региону степная ночница приводится под названием усатая ночница [Швецов, Смирнов, Монахов, 1984; Борисова и др., 2001; Ботвинкин, 2002; Попов, 2011].

Евразийский суббореальный вид. Распространен в степных и лесостепных районах от Малой Азии и Крыма до Забайкалья и Монголии, северо-восточного Китая и Кореи [Банников, 1954; Benda, Tsytsulina, 2000; Крускоп, 2012]. В Бурятии вид находится на северной окраине ареала. Здесь достоверно известно обитание в южных и центральных районах Селенгинского среднегорья (Кяхтинский, Джидинский и Селенгинский районы) [Ботвинкин, 2002], возможны встречи в степных и лесостепных ландшафтах других районов. Обитают они в степных биотопах, попадаются в постройках человека [Фетисов, 1949; Ботвинкин, 2002]. Укрываются в трещинах камней, в пустотах отдельно стоящих домов. Зимних находок в республике нет. Предполагаются сезонные миграции, в то же время не исключается оседлый образ жизни [Ботвинкин, 2012].

\section{8. Восточная ночница - Myotis petax Hollister, 1912}

Ранее восточная ночница рассматривалась в группе подвидов водяной ночницы M. daubentonii. Данные генетического и морфологического анализа позволили установить ее видовую самостоятельность [Matveev, Kruskop, Kramerov, 2005]. Во всех предыдущих публикациях по Байкальскому региону она приводится как ночница водяная M. daubentonii [Юдин, Галкина, Потапкина, 1979; Швецов, Смирнов, Монахов, 1984; Борисова и др., 2001; Ботвинкин, 2002; Попов, 2011].

Азиатский вид умеренного пояса. Распространена в лесной, лесостепной и степной зонах от восточного Казахстана и Западной Сибири до Сахалина, Курильских островов и Японии, на юг до Тывы, Монголии, северной части Китая, Корея [Matveev, Kruskop, Kramerov, 2005]. На территории Бурятии встречается во всех районах, самый обычный вид среди рукокрылых. Обитание связано с реками и озерами в разных ландшафтах от равнины до высокогорья, убежищами служат трещины скал, каменистые осыпи, дупла, постройки человека. Зимуют в пещерах и карстовых полостях с подходящим микроклиматом [Ботвинкин, 2002].

\section{9. Сибирская ночница - Myotis sibirica Kaschenko, 1905}

Ранее рассматривалась как подвид в составе M. brandtii ночница Брандта, в настоящее время она выделена в самостоятельный вид [Kruskop et al., 2012]. В ранних публикациях по Бурятии сибирская ночница указана как ночница Брандта [Швецов, Смирнов, Монахов, 1984; Борисова и др., 2001; Ботвинкин, 2002].

Сибирско-восточноазиатский вид. Распространен в лесной зоне от р. Обь и Алтая до Приморья, Сахалина, Курил, Камчатки, Японии и Кореи [Крускоп, 2012]. В Бурятии встречается во всех районах, только нет сведений из Станового нагорья, но вероятность обитания не исключается. Лесной вид, обитает в горах до верхней границы леса. Живет оседло, зимует в пещерах. В пещере Долганская Яма в Баунтовском районе сибирская ночница зимой входит в число доминирующих по численности рукокрылых [Ботвинкин др., 2001; Ботвинкин, 2002]. 


\section{0. Сибирский ушан или ушан Огнева - Plecotus ognevi Kishida, 1927}

Прежде он рассматривался в составе вида бурый (обыкновенный) ушан P. auritus [Громов, Баранова, 1981; Стрелков, 1988]. В настоящее время на основании генетического и морфологического анализа подтверждена видовая его самостоятельность [Spitzenberger et. al., 2006; Крускоп и др., 2007; Булкина, Крускоп, 2009]. В предыдущих публикациях по Байкальскому региону сибирский ушан идет под названием бурый ушан [Швецов, Смирнов, Монахов, 1984; Борисова и др., 2001; Попов, 2011].

Восточносибирско-восточноазиатский вид умеренного пояса, ареал которого охватывает территорию от Алтая и среднего течения Енисея до Сахалина и северо-восточного Китая [Крускоп, 2012]. Встречается практически на всей территории Бурятии, не известен из Станового нагорья, но не исключается там его обитание. Довольно эвритопный вид, населяет биотопы различных ландшафтов, но предпочитает лесные местообитания, поднимается до субальпийского пояса [Фетисов, 1936; Швецов, 1977; Ботвинкин, 2002]. Оседлый вид, зимовки обычно располагаются в пещерах. Среди зимующих рукокрылых в пещерах региона он занимает по численности доминирующее положение, например, в Долганской Яме, более $60 \%$ особей принадлежат сибирскому ушану [Ботвинкин и др., 2001].

\section{1. Двухцветный кожан - Vespertilio murinus Linnaeus, 1758}

Евразийский вид умеренного и субтропического пояса. В Бурятии находится на северной окраине ареала (отмечен в нескольких точках в Западном Прибайкалье) [Ботвинкин, 2002; Попов, 2011]. Зарегистрирован в Восточном Саяне (Тункинский район, средняя часть р. Иркут), Прибайкалье (р. Переемная, села Танхой, Творогово, дельта р. Селенги), Селенгинском среднегорье (Кяхтинский, Джидинский, Мухоршибирский, Иволгинский, Заиграевский, Хоринский районы, окр. г. УланУдэ) [Фетисов, 1949, 1953; Швецов, 1977; Швецов, Смирнов, Монахов, 1984; Борисова и др., 2001; Ботвинкин, 2002], на юге Витимского плоскогорья. Обитает в лесостепных и степных ландшафтах, места встреч обычно приурочены к долинам рек. Убежищами служат постройки человека, где прячутся за обшивкой стен, наличниками, в чердаках и других укромных местах, трещины скал, осыпи камней, пустоты за корой и дупла деревьев [Фетисов, 1949, 1953; Швецов, 1977; Ботвинкин, 2002].

\section{2. Восточный кожан - Vespertilio sinensis Peters, 1880}

Байкало-восточноазиатский вид. Ареал охватывает территорию от Западного Забайкалья через восточную Монголию, северо-восточный и восточный Китай, Приморье, Сахалин, Японию до Корейского полуострова, Тайваня, [Крускоп, 2012]. В Бурятии находится на западной окраине ареала, отмечено здесь несколько точек встречи: Селенгинское среднегорье (с. Цакир (Закаменский р-н), окр. с. Дырестуй, левобережье р. Джида (Джидинский р-н), с. Иро (Селенгинский р-н) и южная часть Прибайкалья (дельта р. Селенги) [Швецов, Смирнов, Монахов, 1984; Борисова и др., 2001; Ботвинкин, 2002]. Обитает в степных ландшафтах, убежищами служат каменные останцы, предпочитает постройки человека. Перелетный вид, зимует за пределами региона, но места зимовок не установлены [Ботвинкин, 2002].

23. Северный кожанок-Eptesicus nilssonii Keyserling et Blasius, 1839

Евразийский вид, распространенный в основном в умеренном поясе. В Бурятии встречается во всех районах. Обитает в различных лесных биотопах, в горах 
поднимается до предгольцового редколесья, в лесостепных и степных ландшафтах может обитать в древесной растительности в поймах рек, населенных пунктах [Фетисов, 1936; Швецов, Смирнов, Монахов, 1984; Ботвинкин, 2002]. Убежищами служат расселины в скалах, дупла, постройки человека. Северный кожанок не относится к перелетным видам, совершает сезонные кочевки. Зимой в пещерах обнаруживается редко, вероятно, зимует в других местах [Ботвинкин, 2002].

\begin{tabular}{c}
\hline ОТРЯД ЗАЙЦЕОБРАЗНЫЕ - LAGOMORPHA \\
BRANDT, 1855 \\
\hline
\end{tabular}

\section{Семейство Пищуховые - Ochotonidae Thomas, 1897}

\section{4. Даурская пищуха - Ochotona dauurica (Pallas, 1776)}

Центральноазиатский вид. В Бурятии представлен периферийными популяциями, распространен в Селенгинском среднегорье, северная граница проходит по Тарбагатайскому и Иволгинскому районам. Живет в открытых безлесных пространствах по предгорьям низкогорных и среднегорных хребтов и сопок, предпочитаемые биотопы - ложбины и овраги в степи с наличием кустарников (Борисова и др., 2001).

\section{5. Алтайская пищуха - Ochotona alpina Pallas, 1773}

Южносибирско-монгольский вид, ареал охватывает горные системы Алтая, Монгольского и Гобийского Алтая, Саян, Забайкалья, Хангая и Северного Китая [Громов, Ербаева, 1995]. В Бурятии характер распространения не ясен, вероятно, находится на северной и восточной окраине ареала. Ю. Г. Швецов [Швецов, Смирнов, Монахов, 1984] не включает данный вид в список млекопитающих бассейна оз. Байкал в пределах Бурятии. Имеются сведения об обитании алтайской пищухи в Прибайкалье на Баргузинском хр., п-ве Святой Нос [Туров, 1936] и Байкальском хр. [Лисовский, 1999]. В Восточном Саяне - редкий вид (Попов, Гулгонов, Китаев, 2017). Населяет каменистые россыпи и скалы в высокогорном и таежном поясе хребтов.

\section{6. Северная пищуха - Ochotona hyperborea Pallas 1811}

Североазиатско-дальневосточный вид, встречается по горным системам от Енисея до Тихого океана в пределах северной и средней части умеренного и субарктического поясов [Громов, Ербаева, 1995]. В Бурятии обычна в каменистых россыпях Восточного Саяна, хребтов Прибайкалья, Станового нагорья, Витимского плоскогорья и в горах некоторых хребтов Селенгинского среднегорья (Малханский) и обрамляющих его Джидинского и Чикойского хребтов. Местообитания приурочены к россыпям и скалам высокогорий и лесного пояса.

\section{Семейство Зайцевые - Leporidae Fischer, 1817}

\section{7. Заяц беляк - Lepus timidus Linnaeus, 1758}

Евразийско-североамериканский вид лесной и лесостепной зон [Громов, Ербаева, 1995]. В Бурятии распространен во всех районах. Обитатель различных 
лесных биотопов, поднимается до подгольцового и иногда до гольцового пояса. Предпочитает лесные участки с примесью берез, осин с зарослями кустарников и хорошо развитым травостоем.

\section{8. Заяц-толай - Lepus tolai Pallas, 1778}

В некоторых работах по Байкальскому региону идет под названием капский заяц Lepus capensis [Борисова и др., 2001].

Североафриканско-азиатский вид семиаридных и аридных зон: северо-восточные берега Каспийского моря, Казахстан, Центральная Азия, Алтай, Тува, Забайкалье, Индия, Афганистан, Пакистан, Иран, Аравийский п-ов [Громов, Ербаева, 1995]. В Бурятии обитает на северной окраине ареала, встречается в южных и центральных районах Селенгинского среднегорья (до Гусиного озера на севере): Кяхтинский, Джидинский, Бичурский, Селенгинский районы. Некоторые исследователи [Швецов, Смирнов, Монахов, 1984; Борисова и др., 2001] в область распространения зайца-толая в Бурятии включают Закаменский, Иволгинский, Тарбагатайский и юг Заиграевского района. По нашим данным и сведениям местных жителей, здесь он уже не встречается (Доржиев, Носков, 1983). Населяет степные биотопы с хорошо развитым травянистым покровом, зарослями чия, кустарниками караганы, ивы, облепихи.

ОтРяД ГРЫЗУНЫ - RODENTIA

BOWDICH, 1821

\section{Подотряд Белкообразные - Suborder Sciuromorpha Brandt, 1855}

\section{Семейство Беличьи -Sciuridae Fischer, 1817}

\section{9. Обыкновенная летяга - Pteromys volans Linnaeus, 1758}

Восточноевропейско-североазиатско-дальневосточный вид лесной и лесотундровой зоны: распространен от Восточной Прибалтики и Кольского п-ва до Тихого океана, включая острова Сахалин и Хоккадо, на юге охватывает Северную Монголию, Северо-Восточный Китай и Корейский п-ов. В Бурятии встречается в лесах всех районов. Обитатель различных лесных местообитаний горно-таежного ландшафта.

\section{0. Обыкновенная белка - Sciurus vulgaris Linnaeus, 1758}

Евразийский вид лесотундровой, лесной и лесостепной зон умеренного пояса. В Бурятии встречается в лесах различного типа во всех районах.

31. Азиатский бурундук - Tamias sibiricus Laxmann, 1769.

Восточноевропейско-североазиатско-дальневосточный вид лесной зоны: от Карелии до Тихого океана, включая Северную Монголию, Северо-Восточный Китай и Корейский п-ов [Громов, Ербаева, 1995]. В Бурятии обитает в различных типах лесов во всех районах.

32. Длиннохвостый суслик - Urocitellus undulatus Pallas, 1779

В предыдущих работах по Южной Сибири данный вид обозначен как длиннохвостый суслик с разными латинскими названия Citellus eversmani [Швецов, 
Смирнов, Монахов, 1984), Citellus undulatus (Швецов, 1977; Юдин, Галкина, Потапкина, 1979; Лямкин, 2002; Попов, 2011] и Spermophilus undulatus [Борисова и др., 2001]. В сводке «Млекопитающие России» [Павлинов, Лисовский, 2012] русское название дается как восточный длиннохвостый суслик. Мы придерживаемся названия, приведенного в сводке «Млекопитающие России...» [2019], «длиннохвостый суслик Urocitellus undulatus».

Длиннохвостый суслик Urocitellus undulatus - восточносибирский вид, распространенный от Восточного Саяна (района Красноярска) до Приамурья западнее Буреи, охватывает Забайкалье и прилегающие территории Монголии. На севере обитает между Вилюем и Леной и небольшой изолят имеется севернее Вилюя. На юге распространен до Хангая, Монгольского Алтая. В Бурятии распространен в большинстве районах, за исключением Северо-Восточного Прибайкалья (долина p. Верхняя Ангара, западный склон Баргузинского хребта, п-ов Святой Нос) и Станового нагорья. Обитает в открытых ландшафтах по межгорным котловинам (степи и луга по предгорьям и долинах рек) и на альпийских лугах в подгольцовом поясе Восточного Саяна и Хамар-Дабана. Равнинные и высокогорные популяции изолированы таежным поясом (Швецов, Смирнов, Монахов, 1984; Бадмаев, 2007).

\section{3. Монгольский сурок (Тарбаган) - Marmota sibirica Radde, 1862}

Центральноазиатский вид, основной ареал в северной половине Монголии, за ее пределами встречается в Восточном Синьзяне, Туве, Забайкалтье, Северо-Восточном Китае. В Бурятии находится на северной окраине ареала, обитает в Селенгинском среднегорье: Закаменский, Кяхтинский, Джидинский, Бичурский, Мухоршибирский, Селенгинский, Иволгинский, Тарбагатайский, Заиграевский, Хоринский и Кижингинский районы. Распространен спорадично, особенно в северной части среднегорья, где известно несколько изолированных популяций. В Мондах Тункинского района в настоящее время не обитает. Раньше здесь отмечались немногочисленные колонии [Иванов, 1950], затем они исчезли (Попов, Гулгонов, Китаев, 2017). В 60-х годах тарбаганы вновь появились, в 1965 г. в верховьях Иркута были обнаружены довольно большие колонии [Литвинов, Тарасов, 1967]. Их в настоящее время нет. Тарбаганы населяют предгорные и горные степи (Швецов, 1978).

34. Камчатский, или чёрношапочный, сурок - Marmota camtschatica Pallas, 1811

Восточносибирский вид, встречающийся от северо-восточного Прибайкалья (Баргузинский и Икатский хребты) на северо-восток до Камчатки и Корякского нагорья. Ареал сильно фрагментирован и состоит из многих изолированных популяций. Выделяют три крупных участка: первый занимает территорию от Прибайкалья до верховий Алдана, второй якутский — междуречье Лены и Колымы от моря Лаптевых до Охотского, на юг до верховий Маи, третий камчатский - Камчатка и Корякское нагорье. Соответственно они образуют три четко обособленных подвида [Павлинов, Лисовский, 2012]. В Бурятии вид находится на юго-западной границе ареала, встречается в хребтах северо-западного и северо-восточного Прибайкалья (северная часть Байкальского, Баргузинский и северная часть Икатского хребтов), Станового нагорья (хребты Южно-Муйский, Северо-Муйский, Верхнеангарский, Сынныр). Сурки населяют сухие горные тундры и луга альпийского пояса вблизи истоков горных рек и берегов озер, наиболее оптимальными 
местообитаниями являются субальпийские луговины с выходами каменистых россыпей и буграми мелкозема, менее охотно занимают заросли кедрового стланика и криволесье [Жаров, 1970; Швецов, 1977; Бадмаев, 2010; Козулин и др., 2016].

\section{Семейство Бобровые - Castoridae Hemprich, 1820}

\section{5. Обыкновенный бобр - Castor fiber Linnaeus, 1758}

Голоарктический вид, распространенный в лесной зоне. В Бурятии известен единственный участок его обитания в Восточном Саяне - p. Ока (урочище Тухэрен-Тала) в Окинском районе республики [Бадмаев, 1993]. Данная популяция не относится к тувинскому подвиду, а является одним из европейских подвидов, акклиматизированных ранее в районе Братского водохранилища [Борисова и др., 2012]. Обитание бобра обычно бывает связано с реками и озерами.

\section{Семейство Мышовковые - Sminthidae Brandt, 1855}

\section{6. Лесная мышовка - Sicista betulina Pallas, 1779}

Евразийский бореальный вид, распространенный от Альп, Карпат, Предкавказья и Прибальтики до Восточного Прибайкалья и Западного Забайкалья. В Бурятии находится на восточной периферии ареала, обитает в Восточном Саяне, во всех районах Прибайкалья, обычен на Хамар-Дабане, редок на других хребтах, отловлены на Малом Хамар-Дабане и Улан-Бургасах [Юдин, Галкина, Потапкина, 1979; Матурова, 1982; Швецов, Смирнов, Монахов, 1984]. Обитает в различных лесных биотопах, при этом предпочитает разреженные смешанные и лиственные леса и кустарники на сырой почве с густым травянистым покровом.

\section{Семейство Пятипалые тушканчики - Allactagidae Vinogradov, 1925}

\section{7. Тушканчик-прыгун - Allactaga sibirica Forster, 1778}

Центральноазиатский суббореальный вид. В Бурятии проходит северная граница ареала. Распространен по Селенгинскому среднегорью (южные и часть центральных районов Бурятии) на севере до Иволгинской котловины. Обитает по сухим степных местообитаниям, предпочитает участки с каменистым и уплотненным грунтом.

\section{Семейство Хомяковые - Cricetidae Fischer, 1817}

\section{8. Хомячок Кэмпбелла - Phodopus campbelli Thomas, 1905.}

Ранее относили в состав джунгарского хомячка Phodopus (Cricetiscus) sungorus Pallas,1773. В некоторых старых работах он идет под названием джунгарский хомячок [Фетисов, 1936; Швецов, Смирнов, Монахов, 1984].

Южносибирско-монгольский вид, встречающийся в степных и полупустынных зонах Монголии, Северного Китая, Горного Алтая, Тувы, Забайкалья. В Бурятии проходит северная граница ареала, занимает ограниченную территорию в Джидинском и Кяхтинском районах, где отмечен в нижней части долины р. Джиды, 
предгорьях хр. Малый Хамар-Дабан и устье р. Чикой. Обитает в сухих степях, предпочитает разреженную мелкодерновинно-злаковую растительность, тяготеет также к залежам, животноводческим стоянкам с участками сорняков [Швецов, Смирнов, Монахов, 1984].

39. Барабинский хомячок-Cricetulus barabensis Pallas, 1773

В некоторых ранних работах русское название дается как даурский хомячок.

Азиатский суббореальный вид степной зоны, обитает от Прииртышья до Приморья, на юге распространен в Северной Монголии, Северном и Северо-Восточном китае, на Корейском п-ве. В Бурятии встречается во всех районах Селенгинского среднегорья, на Витимском плоскогорье, в Прибайкалье - в Усть-Селенгинской котловине, включая дельту р. Селенги, Баргузинской котловине, в Восточном Саяне - Мондинской котловине (верхняя часть долины Иркута, Тункинский район) [Швецов, Смирнов, Монахов, 1984; Попов, Гулгонов, Китаев, 2017]. Населяет степные местообитания и агроценозы, предпочитает разнотравно-злаковые степные участки с зарослями мелких кустарников, залежи и поля с сорняками.

40. Забайкальский хомячок - Cricetulus pseudogriseus Orlov et Iskhakova, 1975

Таксономический статус забайкальского хомячка разные авторы трактуют неоднозначно. Некоторые рассматривают его в составе вида C. barabensis [Лебедев, Лисовский, 2008; Павлинов, Лисовский, 2012], другие - как самостоятельный вид [Орлов, Исхакова, 1975; Соколов, Орлов, 1980; Малыгин и др., 1992]. В работах, посвященных млекопитающим Байкальского региона, забайкальского хомячка приводят как отдельный вид [Швецов, Смирнов, Монахов, 1984; Борисова и др., 2001]. В данной работе мы придерживаемся взглядов последних авторов, исходя из того, что в зоне симпатрии в Забайкалье эти формы экологически довольно хорошо дифференцированы, особенно по местообитаниям, и у них здесь отсутствует межвидовая гибридизация или она минимальна [Поплавская и др., 2011], хотя их потомства, полученные в экспериментальных условиях, плодовиты. Несомненна, генетически эти формы близки, вероятно, они достигли ранга полувидов. В двух последних сводках по млекопитающим России [Павлинин, Лисовский, 2012; Лисовский и др., 2019] они приводятся в составе одного вида Cricetulus barabensis.

Монгольский вид, распространенный от Центральной Монголии до Большого Хингана, на севере доходит до юго-западной части Забайкалья, на юге - до Северной Гоби [Соколов, Орлов, 1980; Швецов, Смирнов, Монахов, 1984]. В Бурятии проходит северная граница ареала, известен из Кяхтинского района, предполагается обитание в Джидинском и Селенгинском районах [Борисова и др., 2001]. Населяет практически такие же местообитания как и барабинский хомячок, но более сухолюбив [Борисова и др., 2001].

41. Длиннохвостый хомячок - Cricetulus longicaudatus Milne-Edwards, 1867

Центральноазиатский вид, Тува, Забайкалье, Хангай, Монгольский и Гобийский Алтай, Алашань, Нан-Шань. В Бурятии находится на северной границе ареала, он обнаружен только в долине нижнего течения р. Джида (окр. с. Боци, южная периферия Баргойской степи) [Флинт, 1966; Швецов, Смирнов, Монахов, 1984]. Обитает в сухих степях с выходами скал, поросшей кустарниками караганы с полынью и злаками. 


\section{2. Лесной лемминг — Myopus schisticolor Lilljeborg, 1844}

Североевразийский бореальный вид, распространный от Скандинавии до Камчатки, на юге охватывает Северную Монголию, Северо-Восточный Китай, Корею, Сахалин и северные Японские острова. В Бурятии обитает во всех высокогорных и среднегорных хребтах. Населяет хвойные леса с влажной почвой и хорошо развитым моховым покровом от предгорного лесного до подгольцового пояса.

\section{3. Амурский лемминг - Lemmus amurensis Vinogradov, 1924}

Систематика еще не определенна. В последних сводках по млекопитающим России идут под разным статусом. В одном из них идет как самостоятельная форма $L$. amurensis [Павлинин, Лисовский, 2012], в другом — в составе L. lemmus как полувид [Лисовский и др., 2019].

Восточнопалеарктический бореальный вид, ареал которого охватывает Западное Забайкалье, север Приамурья, горные системы Северо-Восточной Сибири и Камчатку. В Бурятии находится на западной окраине ареала, известно обитание на Витимском плоскогорье в долине р. Большой Амалат (бассейн р. Цыпа) (Баунтовский район) [Галкина, 1980].

\section{4. Ондатра - Ondatra zibethicus Linnaeus, 1766}

Североамериканский вид, акклиматизированный в 20-м столетии в умеренном поясе Евразии, в том числе в Бурятии. Обитает на многих водоемах республики, где есть благоприятные местообитания - озера, крупные и средние реки, их протоки и старицы со слабым течением. Предпочитает озера с камышом и тростником, болотами, особенно с кочкарниками.

\section{5. Красносерая полёвка - Craseomys rufocanus Sundevall, $\mathbf{1 8 4 6}$}

Раньше использовалось название Clethrionomys rufocanus. Евроазиатский бореальный вид, ареал его охватывает таежные и горно-таежные районы Северной Евразии от Скандинавии проходит через всю Сибирь до Камчатки, южная граница проходит по средней Волге, Уралу, Монгольскому Алтаю, Хангаю, Хэнтэю, Большому и Малому Хингану, Чанбайшаню, Корейскому п-ву, Хокайдо и прилегающим островам. Обитает в Центральном и Южном Китае, Бирме [Соколов, Орлов, 1980; Zhang et al., 1997; Shenbrot, Krasnov, 2005; Громов, Баранова, 1981; Павлинов, Лисовский, 2012]. В Бурятии встречается во всех районах. Лесной вид, предпочитает темнохвойные леса, занимает другие типы лесов, кустарниковые и луговые местообитания в горах.

46. Красная полёвка - Myodes rutilus Pallas, 1779

В ранних работах идет под названием Clethrionomys rutilus. Голоарктический гипоарктобореальный вид, занимает лесотундровую, таежную, лесостепные зоны, в горах поднимается до подгольцовых редколесий. Южные границы в Азии проходят по северному Казахстану, Алтаю, Саянам, Хангаю, Хэнтею, Большому и Малому Хингану, Чанбайшаню, Корейскому п-ву, Хокайдо и прилегающим островам [Соколов, Орлов, 1980; Zhang et al., 1997; Shenbrot, Krasnov, 2005; Громов, Баранова, 1981; Павлинов, Лисовский, 2012]. В Бурятии водится во всех районах. Типичный обитатель различных лесных, лесостепных и горно-тундровых местообитаний.

\section{7. Тувинская полевка - Alticola tuvinicus Ognev, 1950}

Раньше рассматривался как подвид горной серебристой полевки Alticola argentatus. Тувинская полевка относится к монгольско-южносибирской 
ареалогической группе. Область распространения его охватывает северную часть Монгольского Алтая, Танну-Ола, хр. Академика Обручева, северное Прихубсугулье, Кузнецкий Алатау, на Байкале о-в Ольхон, соседние острова и близлежащее побережье озера [Павлинин, Лисовский, 2012]. В Бурятии вид еще достоверно не найден, но его поселения отмечены в гольцах Мунку-Сардыка (Восточный Саян) с монгольской стороны [Литвинов, Базардорж, 1992]. По всей вероятности, он распространен несколько шире и заходит по гольцам Мунку-Сардыка на территорию Бурятии (государственная граница проходит по водоразделу данного хребта). Места обитания, судя по данным из северного Прихубсугулья и Ольхона [Литвинов, 1982; Литвинов, Базардорж, 1992], приурочены к россыпям, расщелинам, выходам коренных пород, останцам преимущественно в горно-лесостепном поясе. Эти полевки при наличии подходящего каменистого субстрата поселяются среди лесной растительности. Редко встречаются в гольцовом поясе.

48. Большеухая полёвка - Alticola macrotis Radde, 1861

Южносибирский горно-тундровый вид. По Бурятии проходит восточная окраина ареала, распространена по гольцам и горным тундрам Восточного Саяна, Хамар-Дабана, Байкальского и Баргузинского хребтов [Юдин, Галкина, Потапкина, 1979; Швецов, Смирнов, Монахов, 1984; Литвинов, 1992; Павлинов, Лисовский, 2012]. Населяет гольцы и горные тундры.

49. Лемминговидная полёвка - Alticola lemminus Miller, 1899

Ранее рассматривался как подвид большеухой полевки A. macrotis [Громов, Поляков, 1977; Громов, Ербаева, 1995]. Выделен в самостоятельный вид на основании морфологического и кариологического анализа [Васильева и др., 2008]. Северо-восточносибирский горно-тундровый вид: Становое нагорье, Становой хр., Джугджура, хребты Верхоянья, Колымского и Корякского нагорий, Чукотки [Павлинов, Лисовский, 2012]. В Бурятии представлена периферийными популяциями, проходит юго-западная граница ареала. Обитает в горных каменистых тундрах Станового нагорья.

\section{0. Водяная полёвка - Arvicola amphibius Linnaeus, 1758}

В некоторых работах представлена под названием Arvicola terrestris, которое считается синонимом Arvicola amphibious.

Евразийский полизональный вид. В Бурятии находится на восточной окраине ареала. Распространен спорадично по северным и северо-западным районам. Отмечен в Восточном Саяне в долине р. Иркута и, возможно, бассейне p. Ока [Юдин, Галкина, Потапкина, 1979; Литвинов, 1992; Борисова и др., 2001]. В Северном Прибайкалье отловлены в устье Кичеры и Верхней Ангары [Ступина, 1961; Швецов, Смирнов, Монахов, 1984] и бассейне р. Тыя в Байкальском хребте [Лямкин, 2002]; на северо-западе Витимского плоскогорья - у Баунтовских озер [Попов, Матвеев, 2006]. Обычно водяные полевки обитают по берегам рек и на лугах вблизи них.

\section{1. Китайская полёвка - Lasiopodomys mandarinus Milne-Edwards, 1871}

Восточноазиатский вид. Область распространения охватывает районы, прилегающие к Желтому морю от р. Янцзы до Корейского полуострова; хребты Циньлин и Люйляншань, Большой Хинган. За пределами ее существуют изоляты в Северной Монголии и в юго-западном Забайкалье (бассейн рек Селенги и Орхона). 
Так, известна китайская полевка из юга Селенгинского среднегорья и сопредельных к нему районов Северной Монголии в низовье р. Орхон и среднего течения p. Селенга, Восточного Хангая [Банников, 1954; Соколов, Орлов, 1980; Швецов, Смирнов, Монахов, 1984]. В Бурятии находится на северной окраине ареала, отловлена в Закаменском, Джидинском и Селенгинском районах: бассейн среднего и нижнего течения р. Джида (южное предгорье хр. Малый Хамар-Дабан от левобережья нижней части р. Хамней, склоны Джидинского и Боргойского хребтов, Боргойская котловина) [Фетисов, 1955; Швецов, Смирнов, Монахов, 1984; Калинина, Нихилеева, 1991; Сморчакова, 2001]. Самая северная точка поимки зарегистрирована в Селенгинском районе на северо-западном предгорье хр. Боргойский в окр. с. Сосновка и оз. Торм (Калинина, Нихилеева, 1998). Характер распространения данной полевки по бассейну р. Джида нуждается в уточнении, вероятно, они обитают в других местах, в частности, в окр. с. Мыла (долина р. Бильчир, правый приток р. Хамней, берет начало с хр. Малый Хамар-Дабан), где осенью местное население собирает из кладовых каких-то полевок корни стеллеры карликовой Stellera chamaejasme. По их описанию, зверьков и их колонии мы предположительно отнесли китайским полевкам. Населяют эти грызуны степные, лугостепные и разнотравные луга с участием стеллеры карликовой по предгорьям, склонам и вершинам сопок [Фетисов, 1955; Калинина, Нихилеева, 1998].

52. Узкочерепная полёвка - Lasiopodomys gregalis Pallas, 1779

Восточноевропейско-североазиатский вид арктического, субарктического и умеренного поясов. Ареал состоит из нескольких участков от Европейского Севера и Западного Приуралья до Анадырьского нагорья на востоке, на юге граница проходит по Восточному Казахстану, Северной и Центральной Монголии, Большому Хингану. Участки обитания известны в тундрах от устья Печоры до Ямала, восточнее от Анабара до Колымы. Изоляты имеются в остепнённой зоне Центральной Якутии по долинам Лены, Вилюя, Алдана, а также в степях Среднего Приамурья и в среднем течении Хуанхэ [Zhang et al., 1997; Shenbrot, Krasnov, 2005; Павлинов, Лисовский, 2012]. В лесостепной и степной зонах распространение относительно равномерное. В Бурятии узкочерепная полевка встречается в лесостепных районах Селенгинском среднегорье (нижняя часть долины р. Джида, бассейны рек Чикоя, Хилка, Селенги, Уды). В Прибайкалье отмечена в Усть-Селенгинской впадине, включая дельту р. Селенги, бассейне нижнего течения р. Итанца, предгорьях хребтов Морской и Улан-Бургасы, самая северная точка обитания - окр. сел Турунтаево и Зырянска (Прибайкальский район) [Швецов, Смирнов, Монахов, 1984]. На Витимском плоскогорье узкочерепные полевки отловлены в долине р. Индола (бассейн оз. Большое Еравное) [Дагдуева, Бороноева, 2007). В Восточном Саяне обычна в Мондинской котловине, но не встречается в других котловинах Тункинской котловины (Литвинов, 1992). Типичными местообитаниями служат степные и лесостепные участки с лугово-степной, разнотравностепной растительностью с кустарниками по ложбинам и днищам падей, окраины полей, заросших сорняками, старые залежи [Фетисов, 1942; Матурова, Доржиев, Иванова, 1977; Швецов, Смирнов, Монахов, 1984].

53. Полёвка-экономка - Alexandromys оесопотиs Pallas, 1776

Восточноевразийско-североамериканский гипоаркто-бореальный вид. Бурятия полностью входит в ареал вида. Населяет подгольцовые, лесные и лесостепные 
местобитания, предпочитает различные лесные биотопы с кустарниками, речные долины и поймы с зарослями кустарников с богатым разнотравьем и увлажненной почвой, избегает сухие биотопы.

54. Полёвка Максимовича - Alexandromys maximowiczii Schrenk, 1859

Раньше использовалось название унгурская полевка. Восточносибирскодальневосточный вид северной части суббореального пояса, ареал тянется от Байкала до побережья Охотского моря, южная граница проходит по Северной Монголии, верхнему Приамурью и Северо-Восточному Китаю, северная граница по Витимскому плоскогорью, Юго-Восточной Якутии. В Бурятии находится на северо-западной окраине ареала. В Восточном Прибайкалье отмечена в дельте p. Селенги и на прилегающих склонах Морского хребта, в Западном Забайкалье распространена от р. Селенги на восток по бассейнам правых ее притоков (Уда, Хилок, Чикой) и на Витимском плоскогорье [Швецов, 1977; Галкина, 1986; Лямкин, 2002; Дагдуева, Бороноева, 2007]. Обычно обитает в открытых местообитаниях в поймах рек, на лугах и окраинах болот, в кустарниках, травянистых ложбинах на склонах и среди полей.

55. Муйская полёвка - Alexandromys mujanensis Orlov et Kovalskaya, 1978

Эндемик Байкальского региона. Данная полевка выделена в самостоятельный вид в середине 70-х годов прошлого столетия на основе хромосомных и гибридологических данных из пос. Муя (приток р. Витим) Муйского района Бурятии [Орлов, Ковальская, 1975, 1978]. По морфологическим характеристикам она сходна с полевкой Максимовича. В настоящее время известно обитание муйской полевки в Муйско-Куандинской, Баунтовской и Баргузинской котловинах [Орлов, Ковальская, 1978; Голенищев и др., 2018; Картавцева и др., 2019]. Как видно, практически весь ареал находится в пределах северных районов Бурятии, распространение весьма мозаичное и, вероятно, эти популяции не имеют между собой контактов. Типичными местообитаниями являются лугово-болотно-кустарниковые сообщества с хорошо развитым травянистым покровом, при этом наибольшее предпочтение отдают хорошо увлажненным кочкарниковым разнотравно-осоковым лугам. Встречаются на окраинах лесов на пограничных участках с лугами, болотами и зарослями кустарников [Лямкин, Малышев, 1980; Лямкин, Пузанов, Малышев, 1983].

56. Восточная, или большая, полёвка - Alexandromys fortis Buchner, 1889

Восточносибирско-дальневосточный вид умеренного пояса, распространен от Байкала (дельта р. Селенги) до устья Амура и Корейского п-ва, при этом северная граница проходит по черте г. Чита, южным районам Амурской области и Хабаровского края, южная окраина охватывает Северную Монголию и Северный Китай. В Бурятии находится на северо-западной окраине ареала. В Прибайкалье восточная полевка отмечена в дельте р. Селенги, в долине р. Итанца, Баргузинской котловине, на южном склоне хр. Улан-Бургасы. В Селенгинском среднегорье особи данного вида отловлены в низовьях р. Уда, бассейнах рек Джида, Хилка, Чикоя, низовьях p. Темник и в долине среднего течения р. Селенги [Фетисов, 1936, 1953; Швецов, Смирнов, Монахов, 1984]. На Витимском плоскогорье отловлены в бассейне оз. Большое Еравное [Дагдуева, Бороноева, 2007]. Оптимальными местообитаниями являются заболоченные или полусухие ложбины вблизи и на берегах рек и озер, 
заросшими густыми зарослями осок, злаков и разнотравья с кустарниками. Проникают иногда в сосновый и смешанный леса, где встречаются на полянах с густой травянистой растительностью [Швецов, Смирнов, Монахов, 1984; Лямкин, 2002].

57. Монгольская полёвка - Alexandromys mongolicus Radde, 1861

Монгольский вид, встречающийся спорадично от Северо-Западной Монголии (Хангай) до западной части Большого Хингана, северная граница проходит по Туве, о. Ольхону и степям бассейна бассейна Амура и Витима в Забайкалье [Павлинов, Лисовский, 2012]. В Бурятии находится на северной окраине ареала. Известна из окр. с Монды (Восточный Саян, Тункинский район) [Фетисов, 1941; Литвинов, Васильев, Ельшанская, 1976], есть указание на находку на Витимском плоскогорье (р. Большой Амалат, п. Байса, Баунтовский район) [Борисова и др., 2001]. Такое разбросанное обитание монгольской полевки предполагает находки ее и в других районах республики. По биотопическому распределению близок обыкновенной полевке. По данным из Монголии [Швецов, Смирнов, Монахов, 1984], населяет преимущественно увлажненные горные степи с зарослями березы с хорошо развитым травянистым покровом, заросли кустарников в нижней части высокогорий и долины ручьев с растительностью из осок и злаков.

\section{8. Обыкновенная полёвка - Microtus arvalis Pallas, 1778}

Транспалеаркт, лесная и лесостепная зоны центральной части Западной и Восточной Европы, Кавказ, Закавказье, Северная Турция, Северный Иран, Северо-Западный Китай, Восточный Казахстан, юг Западной Сибири и юг Восточной Сибири до Байкала. В Бурятии находится на восточной окраине ареала, найдена на южном побережье оз. Байкал в Кабанском районе, также известна в соседнем Слюдянском районе Иркутской области [Фетисов, 1941; Демидович, 1988]. Обычно населяет, судя по другим регионам Сибири, лесные поляны, опушки леса, разреженные смешанные леса, заросли кустарников, лесостепные участки, избегает тайгу, густые смешанные леса [Юдин, Галкина, Потапкина, 1979].

\section{9. Восточноевропейская полёвка - Microtus rossiaemeridionalis Ognev, 1924}

Восточноевропейский вид, в настоящее время его ареал быстро расширяется на восток по Сибири (окр. Новосибирска, Минусинская котловина, Прибайкалье и Забайкалье), отмечен на Дальнем Востоке в окр. Советской Гавани [Павлинов, Лисовский, 2012]. В Бурятии этот вид обнаружен совсем недавно в сентябре 2016 г. в парках г. Улан-Удэ [Моролдоев, Шереметьева, Картавцева, 2017]. Возможность обитания на прилегающих территориях города, в частности, агроценозах не исключается. По предположению указанных авторов, восточноевропейская полевка попала в Улан-Удэ случайно, вероятно, была завезена из других регионов с фуражом, овощами и другими продуктами питания по железной дороге. Такой путь расселения имеет место в другие дальние от основного ареала районы.

\section{0. Темная полёвка - Microtus agrestis Linnaeus, 1761}

Известна еще под названием пашенная полевка Microtus agrestis. Евразийский бореальный вид. Ареал охватывает территорию от Португалии, Англии до и Юго-Восточной Якутии, Северную Монголию, Западный и Северо-Западный Китай [Каталог... 1981]. В список млекопитающих Бурятии включен на основании его обитания в юго-западном Прибайкалье в районе п. Слюдянка и Култук 
в предгорьях хр. Хамар-Дабан вблизи границ с Бурятией [Швецов, Смирнов, Монахов, 1984]. Данная полевка может встречаться, исходя из особенностей требований ее к местам обитания, на северных предгорьях Хамар-Дабана в соседней Торской котловине Тункинского района, возможно, здесь она распространена еще шире. В указанном районе исследования мелких млекопитающих не проведены. На Хамар-Дабане обитает в основном светлохвойных и смешанных сосново-березово-лиственничных лесах, в темнохвойной тайге не обнаружена [Швецов, 1977]. В южной части Приморского хребта (Западное Прибайкалье) наибольшая численность отмечена на высохшем верховом болоте, зарастающим смешанным лесом, а в пойменном калтусе и на берегу речки единична [Швецов, Литвинов, 1967].

\section{Семейство мышиные - Muridae Illiger, 1811}

\section{1. Мышь-малютка - Micromys minutus Pallas, 1771}

Транспалеарктический вид, ареал которого простирается от восточных Пиренеев до Хингана и Японии, также охватывает Северную Монголию, Китай, Северо-Восточную Индию и Вьетнам [Млекопитающие... 1963]. В Бурятии мышьмалютка распространена очень спорадично по всем районам. Стенотоп, типичными местообитаниями являются долины рек с густой высокотравной и кустарниковой растительностью и умеренно увлажненной почвой, иногда населяют разреженные березово-осиновые леса с пышным травостоем, другие биотопы ее не привлекают [Юдин, Галкина, Потапкина, 1979; Швецов, Смирнов, Монахов, 1984; Лямкин, 2002].

\section{2. Восточноазиатская мышь - Apodemus peninsulae Thomas, 1907}

Восточнопалеарктический вид, распространенный от Южной Сибири, среднего бассейна Лены на восток до Охотского моря, на юге граница проходит по Северной Монголии, Приамурью, Приморью и далее полосой проходит по Восточной Азии в Юго-Восточный Тибет, встречается также на островах Сахалин, Хоккайдо и Кюсю [Павлинов, Лисовский, 2012]. В Бурятии населяет все подходящие местообитания во всех районах. Обитает в различных лесах на всех хребтах, предпочитает долины горных речек, нарушенные разреженные закустаренные участки светлохвойных лесов, смешанные леса с кустарниками, зарастающие гари с обильной травянистой растительностью и окрестности полей. При этом избегает увлажненные места.

63. Домовая мышь - Mus musculus Linnaeus, 1758

Космополит, синантропный вид. В Бурятии обитает в населенных пунктах всех районов, в тайге в отдельных охотничьих избушках не встречается. Летом кочует в окружающие населенные пункты местообитания.

64. Серая крыса (Пасюк) - Rattus norvegicus Berkenhout, 1769

Космополит, с человеком заселила все континенты (кроме Антарктиды). В Бурятии обитает во многих населенных пунктах всех районов.

65. Черная крыса - Rattus rattus Linnaeus, 1758

Космополит, с человеком расселилась по всем континентам (кроме Антарктиды). В Бурятии отмечена в населенных пунктах Тункинского района (Восточный Саян) 
[Попов, Матвеев, 2006]. Иногда попадается в г. Улан-Удэ, но насчет постоянного обитания не известно.

66. Когтистая песчанка - Meriones unguiculatus Milne-Edwards, 1867

Монгольский вид. В Бурятии представлена северными краевыми популяциями. Встречается в Селенгинском среднегорье спорадично на территориях Кяхтинского (нижняя часть долины р. Чикой), Джидинского (низовье р. Джида от с. Бургултая и ниже) и Селенгинского районов (окр. с. Дэбэн, Нур-Тухум, западные предгорья Боргойского хр.). Северная граница проходит на левобережной части р. Селенги по оз. Тором (окр. с. Селендума) и устье р. Темник, а на правобережной стороне Селенги - по Боргойскому хребту. Населяет песчаные участки степей, поля и залежи, песчаные карьеры и овраги, обочины дорог, окраины животноводческих стоянок и полевых станов.

\begin{tabular}{c}
\hline ОТРЯД ХИЩНЫЕ - CARNIVORA \\
BOWDICH, 1821 \\
\hline
\end{tabular}

\section{Подотряд Псообразные Suborder Cani for mia Kretzoi, 1938}

\section{Семейство псовые - Canidae Fischer, 1817}

\section{7. Волк - Canis lupus Linnaeus, 1758}

Евразийско-североамериканский полизональный вид. В Бурятии встречается во всех районах. Обитает в различных местообитаниях лесных и лесостепных ландшафтов. На степных участках встречается во время охоты или переходов с одних мест в другие.

\section{8. Красный волк - Cuon alpinus Pallas, 1811}

Центрально-южноазиатский вид, включая Индостан, Индокитай, Малакку, острова Суматру и Яву, а также Памиро-Алай, Тянь-Шань, юг Сибири, Дальний Восток, Япония. В России, вероятно, встречаются особи, заходящие редко из соседних регионов. В сводках последних лет пишут, что документальных находок красного волка на территории России в последние десятилетия нет [Аристов, Барышников, 2001; Павлинов, Лисовский , 2012], а в книге Лисовского с авт. [2019] данный вид в фауне России вообще не указан. Тем не менее, имеются сообщения, хотя несколько устаревшие, о встречах этих хищников в ряде районов Южной Сибири [Туманов, 2009]. В Бурятии они изредка отмечались в Восточном Саяне, Хамар-Дабане [Подаревский, 1936; Скалон, 1936; Смирнов, 1988; Медведев, 1993; Медведев, Бадмаев, 2013]. В 2000 и 2001 гг. в Окинском районе в одной и той же местности в верховье р. Хор (левый приток верхнего течения р. Ока, недалеко от границы Монголии и России) местные скотники (многие из них хорошие охотники) после заезда на летники в мае неоднократно отмечали стаи красных волков из 7-9 особей. Они периодически нападали на ячат и после июня исчезали. Кроме этих сообщений, имеются сведения скотоводов о редких летних заходах красных волков в долину р. Диби (левый приток р. Ока) [Доржиев, Тулуев, 2002]. После 
этого периода в течение почти 20 лет сведения о красном волке с указанных мест не поступали. На прилегающей территории Монголии, откуда предполагаются его заходы, известно немногое [Банников, 1954], последнее свидетельство касается добычи двух красных волков в Прихубсугулье в 1976 г. на перевале Хуутын даваа и в долине р. Жолог-гол [Литвинов, Базардорж, 1992]. Обитатель субальпийского и альпийского поясов со скалами и ущельями, в период дальних кочевок могут появиться и в других местообитаниях.

\section{9. Корсак - Vulpes corsac Linnaeus, 1768}

Восточноевропейско-центральноазиатский суббореальный вид, распространенный от северо-западного Прикаспия, Волжско-Уральских степей на восток до Хингана [Аристов, Барышников, 2001]. В Бурятии проходит северная граница ареала. Встречается в Селенгинском среднегорье в южных и центральных районах републики до черты г. Улан-Удэ По долине р. Джида вверх доходит до Нижнего Торея [Фетисов, 1949; Доржиев, Шаргаев, Матурова, 1979; Швецов, Смирнов, Монахов, 1984]. Типичный обитатель равнинных холмистых степных местообитаний.

70. Обыкновенная лисица - Vulpes vulpes Linnaeus, 1758

Ареал - Евразия (кроме Индии и Индокитая), Северная Африка, Северная Америка, интродуцирован в Австралии. В Бурятии встречается во всех районах. Населяет разнообразные местообитания, предпочитает лесостепные участки, открытые пространства с разреженными лесами, кустарниками, ложбинами, оврагами, поймы рек, сельскохозяйственные угодья.

\section{Семейство медвежьи - Ursidae Fischer, 1814}

\section{1. Бурый медведь - Ursus arctos Linnaeus, 1758}

Евразийско-североамериканский бореальный вид. Северная граница совпадает с границей леса и лесотундры, в Азии южная граница проходит по Гималаю. В Бурятии обитает во всех районах. Населяет преимущественно таежные леса, нередко выходит на берег Байкала, иногда поднимается в высокогорные ландшафты.

\section{Семейство Настоящие тюлени — Phocidae Gray, 1821}

\section{2. Байкальская нерпа - Phoca sibirica Gmelin, 1788}

Эндемик оз. Байкал. Распределена по Байкалу неравномерно. Основные районы обитания связаны с северными и средними акваториями озера. Большие скопления имеются на Ушканьих островах (Пастухов, 1993).

\section{Семейство куньи - Mustelidae Семейство Fischer, 1817}

\section{3. Соболь - Martes zibellina Linnaeus, 1758}

Сибирско-дальневосточный бореальный вид, распространенный от Урала до Охотского моря, на севере доходит до Корякского и Колымского нагорий и Камчатки, южная граница ареала проходит по Северной Монголии, Северо-Восточному Китаю, Корейскому полуострову, обитает на островах Сахалин, Кунашир, Итуруп, Хоккайдо. В Бурятии населяет таежные леса практически на всей 
территории республики. Обычно выбирает глухие, захламленные темнохвойные леса (Монахов, Бакеев, 1981; Черникин, 2006).

74. Росомаха - Gulo gulo Linnaeus, 1758

Евразийско-североамериканский гипоарктобореальный вид. Встречается в таежных лесах и подгольцовом поясе на всей территории Бурятии.

75. Азиатский барсук - Meles leucurus Hodgson, 1847

Евразийский вид, ареал его охватывает Европу и Азию за исключением Восточной и Северо-Восточной Сибири и пустынь Центральной Азии, полуостровов Индостан и Индокитай. Встречается на всей территории Бурятии. Населяет лесные, лесостепные местообитания, в степи обитает в ложбинах и оврагах, заросшими кустарниками, на открытых склонах предгорий и сопок, на террасах речных долин и озер.

\section{6. Солонгой - Mustela altaica Pallas, 1811}

Южносибирско-центральноазиатский суббореальный вид, на востоке ареал доходит до Корейского полуострова. В Бурятии проходит северная граница ареала. В Прибайкалье встречается в Усть-Селенгинской впадине и Баргузинской котловине, Селенгинском среднегорье - по долинам рек Селенги и его притоков Уды, Джиды, Хилка, Чикоя. Населяет лесостепные, степные, лугово-болотные и лугово-кустарниковые местообитания [Швецов, Смирнов, Монахов, 1984; Лямкин, 2002].

\section{7. Ласка - Mustela nivalis Linnaeus, $\mathbf{1 7 6 6}$}

Североафриканско-евразийско-североамериканский полизональный вид. В Бурятии встречается во всех районах. Обитает в разнообразных ландшафтах от равнинных степей и лесостепей до альпийского высокогорья. Обычно придерживается пойм рек, перелесков, опушек, зарослей кустарников, скал и россыпей.

78. Горностай - Mustela erminea Linnaeus, 1758

Евразийско-североамериканский полизональный вид. В Бурятии встречается повсеместно в различных ландшафтах, но тяготеет к околоводным местообитаниям, заболоченным участкам, лесным опушкам, зарослям кустарников, вырубкам.

79. Колонок - Mustela sibirica Pallas, 1773 (сибирский sibirica)

Азиатский темперантный вид, распространенный от Урала до Дальнего Востока и Северо-Восточного Китая, на юг доходит до Тибета и Гималаи, включая Кашмир, Непал, Северную Бирму. Обитает на Японских островах и Тайване и Яве. В Бурятии встречается во всех районах. Населяет разнообразные лесные местообитания, предпочитает хвойные леса, зарастающие вырубки и гари, тяготеет к местам захламленным буреломом.

\section{0. Степной (Светлый) хорь - Mustela eversmanii Lesson, 1827}

Евразийский вид, распространенный по семиаридным ландшафтам от Восточной Австрии до Приамурья, встречается в Крыму, северной половине Центральной Азии, Северо-Восточном Китае, Тибете, Гималаях. В Бурятии проходит северная граница ареала. Обитает в степных и лесостепных местобитаниях Восточного Саяна (Тункинская котловина, долина р. Ока), Селенгинского среднегорья (южные и центральные районы республики), в Прибайкалье - Усть-Селенгинской впадине (Кабанский район), долине Итанцов, Баргузинской котловине, в также на юге Витимского плоскогорья. 


\section{1. Американская норка - Mustela vison Schreber, 1777}

Североамериканский вид. Начиная с 1933 г. не раз выпускали в разных регионах бывшего СССР, в том числе в Сибири. В Бурятию завезена в 1939 г., было выпущена 69 особей в Хоринском районе [Швецов, Смирнов, Монахов, 1984]. Вероятно, часть норок убежала из звероферм, особенно в Кабанском районе, где во второй половине 20-го столетия разводили их в большом количестве. В настоящее время отмечается практически по всей республике: по побережью Байкала, в долине Баргузина, Селенгинском среднегорье, на юге Витимского плоскогорья, Закаменском и Тункинском районах. Населяет небольшие водоемы (озера, протоки, речки) среди лесных ландшафтов, предпочитает места с берегами заросшими древесно-кустарниковой растительностью, захламленными упавшими деревьями.

82. Речная выдра - Lutra lutra Linnaeus, 1758

Североафриканско-евразийский вид. В Бурятии обитает по горным рекам Восточного Саяна (Зун-Мурино, Хонгор- Уула, Иркут, Хойто Ока, Сенца, Тисса, Урик и др.), Прибайкалья (по всем хребтам), верховьях некоторых рек Западного Забайкалья (Джида, Темник и его притоки, Оронгой, Уда, Курба, Чикой, Хилок и др.) [Швецов, Смирнов, Монахов, 1984; Попов, Гулгонов, Китаев, 2017].

\section{Семейство кошачьи — Felidae Fischer, 1817}

\section{3. Ирбис (Снежный барс) - Uncia uncia Schreber, 1776}

Центральноазиатско-южносибирский вид высокогорных хребтов. В Бурятии обитает в Восточном Саяне (Тункинский и Окинский районы) (Медведев, 1992, 1998, 2012). Заходы зарегистрированы на Хамар-Дабан, Джидинский и Малханский хребты, в Баргузинскую котловину и Улан-Бургасы [Доржиев, Цыбиков, 1999; Андронов, 2012; Медведев, 2013]. Местообитание представляет собой высокогорную местность (1500-1700 м. над у.м.), скальники, кедровые массивы.

84. Манул - Otocolobus manul Pallas, 1776

Южносибирско-центральноазиатский суббореальный вид. В Бурятии проходит северная граница ареала. Обитает в Селенгинском среднегорье на севере до Иволгинской котловины и по р. Джиде вверх идет до р. Цакирки [Шаргаев, Матурова, Доржиев, 1979; Швецов, Смирнов, Монахов, 1984]. Зарегистрирован в высокогорье Восточного Саяна [Медведев, 2007; Попов, Гулгонов, Китаев, 2017]. Известна добыча в северной части Баргузинской котловины [Доржиев и др., 1985]. Обитатель холмистых степей с выходами коренных пород, обычно держится около останцов сопок. В высокогогорье встречается в альпийском поясе в местах со скалами и россыпями из крупных камней, где часто обитают пищухи.

\section{5. Рысь - Lynx lynx Linnaeus, 1758}

Евразийский вид умеренного пояса. В Бурятии встречается в лесах всех районов. Обитает преимущественно в хвойных и смешанных лесах, избегает открытые степи, но заходит иногда в разреженные островки предгорных и равнинных сосновых лесов. 


\section{Подотряд Ежеобразные - Suborder Talpomorpha Bugge, 1974}

\section{Отряд ПАРНОКОПЫТНЫЕ - ARTIODACTYLA}

\section{Семейство Свиные - Suidae Gray, 1821}

\section{6. Кабан - Sus scrofa Linnaeus, 1758}

Североафриканско-евразийский вид. В Бурятии обитает на большей ее части: Восточный Саян, Восточное Прибайкалье (кроме северной его части, СевероБайкальский район), Селенгинское среднегорье (за исключением небольших хребтов как Боргойский и Моностой), Витимское плоскогорье, юг Станового нагорья (Южно-Муйский хребет). Обитает в различных лесах, предпочитает кедровые леса, убуры, луговые участки среди леса.

\section{Семейство Оленьи - Cervidae Goldfuss, 1820}

\section{7. Благородный олень - Cervus elaphus Linnaeus, 1758}

В книге «Млекопитающие России» [Павлинов, Лисовский, 2012] азиатские восточные формы (изюбрь и марал) и американский вапити C. canadensis объединены на основании результатов генетических исследований [Ludta et al., 2004; Кузнецова, 2007; Meiri et al., 2018] и рассматриваются как отдельный вид «Изюбрь; Марал - Cervus canadensis Erxleben, 1777» [Павлинов, Лисовский, 2012]. В последней сводке по млекопитающим России (Лисовский и др., 2019) оставлен прежний статус под названием «благородный олень Cervus elaphus». Из-за неудобства использования названия «изюбрь; марал» нами оставлено старое название.

Благородный олень - евразийско-североамериканский вид умеренного пояса. В Бурятии распространен во всех районах. При этом хорошо отличаются две формы: марал (C. e. asiaticus), который населяет Восточный Саян и иногда встречается на Хамар-Дабане, и изюбрь (C. e. xanthopygus) - остальные районы. На Хамар-Дабане отмечаются гибриды между этими подвидами. Населяют различные леса, предпочитают держатся в смешанных и негустых лесах с полянами и относительно хорошим травостоем и подростом.

\section{8. Сибирская косуля - Capreolus pygargus Pallas, 1771}

Восточноевропейско-азиатский вид умеренного пояса, ареал которого занимает территорию от р. Дона и Волги до побережья Тихого океана, на юге - горы Центральной Азии до Восточного Тибета. В Бурятии встречается повсеместно. Обитатель различных лесов в горах и на равнине, предпочитает сосновые и смешанные леса, лесостепные насаждения (Смирнов, 1978).

\section{9. Американский лось - Alces americanus Clinton, 1822}

Раньше род Alces считался монотипическим [Гептнер и др., 1961; Павлинов, 2003]. В настоящее время он разделен на два вида: американский лось и 
европейский лось, которые географически хорошо дифференцированы [Боескоров, 2001; Барышников, Тихонов, 2009]. На данном этапе они имеют статус полувидов в рамках надвида «alces» [Давыдов, Холодова и др., 2007; Рожков и др., 2009]. В сводке «Млекопитающие России» [Павлинов, Лисовский, 2012] приводится отдельно как американский лось Alces americanus, а в более позднем справочнике [Лисовский и др., 2019] эти полувиды рассматриваюся как один вид под старым названием лось Alces alces.

Восточносибирско-североамериканский вид. В Сибири отмечается от Енисея до Корякского нагорья, южная граница проходит по Северной Монголии и Северо-Восточному Китаю. В Бурятии обитает во всех районах. Населяет лесные местообитания в горах, редко встречается в открытой местности.

90. Северный олень - Rangifer tarandus (Linnaeus, 1758)

Евразийско-североамериканский аркто-альпийский вид. В Сибири по хребтам на юг доходит до Алтая, Саян, Тувы, Прихубсугулья, Забайкалья, СихотэАлиня, Северо-Восточного Китая. В Бурятии встречается на хребтах Восточный Саян, Хамар-Дабан, Улан-Бургасы, Баргузинский, Икатский, в горах Северо-Байкальского и Станового нагорьев. Обитает в альпийском поясе хребтов.

\section{Семейство Кабарговые (Кабарожьи) - Moschidae Gray, 1821}

\section{1. Кабарга - Moschus moschiferus Linnaeus, 1758}

Восточносибирско-дальневосточный горно-бореальный вид, ареал простирается от Алтая до Дальнего Востока, обитает на Сахалине, Корее, Монголии и Северо-Восточном Китае. В Бурятии встречается почти во всех районах: горные системы Восточного Саяна, Прибайкалья, Джидинского горного района, некоторые хребты Селенгинского среднегорья, Витимского плоскогорья. Избегает слабо облесенные хребты. Обычные места обитания - леса с хорошо развитой мохово-лишайниковой растительностью с выходами скал, преимущественно в средних частях склонов у горных ручьев, при этом предпочитает держаться на малоснежных участках с уступами на скалах, валежниками, колодниками и хорошо развитым травяным покровом [Устинов, 1961; Швецов, Смирнов, Монахов, 1984].

\section{Семейство Полорогие - Bovidae Gray, 1821}

\section{2. Сибирский козёл (Козерог) - Capra sibirica Pallas, 1776}

Южносибирско-центральноазиатский горный вид: хребты Южной Сибири (Алтай, Саяны), Центральной Азии (Гиндукуш, Памиро-Алай, Тянь-Шань, Джунгарский Алатау, Хангай, Монгольский и Гобийский Алтай, Северный Тибет) и Гималаи. В Бурятии встречается северо-восточной окраине ареала, в Восточном Саяне (Окинский и Тункинский районы). Обычно живет в высокогорном поясе на скалистых участках с альпийскими лугами [Медведев, 2001].

93. Архар, или аргали - Ovis ammon Linnaeus, 1758

Центральноазиатский вид, распространенный в горах Центральной Азии от Тянь-Шаня и Памира до Алтая, Прихубсугулья, Хангая, Тибета и Гималаи 
(Сиккими). В Бурятии аргали зарегистрирован на Восточном Саяне в Окинском районе: в начале 20-го столетия он отмечен В. Ч. Дорогостайским [1918, цит. по Банников, 1954] в истоке р. Иркута; позже, в 1948 г. в верховье р. Жомболок в окр. оз. Хара-Нур видели 8 баранов; в конце ноября 1953 г. еще одного барана загнали собаки на скалу по р. Хорин-Жалга (приток р. Тисса) [Швецов, Смирнов, Монахов, 1984]. По этим данным можно выдвинуть две версии. По одной из них на территорию Окинского района изредка могут заходить кочующие архары из соседнего Прихубсугулья (Монголия), по другой — в определенное время они здесь могли жить постоянно. Во второй половине XX века и начале текущего столетия сведений об обитании аргали в Окинском районе не было, хотя мы здесь работали с перерывами с 1997 г. Это связано, очевидно, с особенностью динамики численности этих животных в соседней Монголии. По учетным данным, в Монголии в 1975 г. насчитывалось около 50 тыс. особей, в 1985 г. - 60 тыс., 2001 г. 3-15 тыс., 2009 г. - 18 тыс. [Амгаланбаатар, Ридинг, Доржиев, 2012]. Прихубсугульская популяция в 1975 г. насчитывала 700 особей, по наблюдениям с конца 90-х гг. прошлого столетия до 2009 г. здесь обитало около 30 особей [Амгаланбаатар, Доржиев, Ридинг, 2014]. В настоящее время данная популяция выросла до 230-250 особей [Амгаланбаатар, личное сообщение]. Они, видимо, начали кочевать более шире, в том числе на север на территорию Восточного Саяна. В последние годы появились вновь сведения о редких встречах аргали местными охотниками в Окинском районе. Для них есть обширные подходящие местообитания на Окинском плоскогорье, Большом Саяне. Это плато и пологие склоны, предгорья со скалами в альпийском поясе с открытыми остепненными участками с относительно богатой травянистой растительностью.

\section{Заключение}

Таким образом, в настоящее время в Республике Бурятия обитает 93 вида диких млекопитающих, относящихся к 6 отрядам, 21 семейству и 57 родам. Потерпели заметные изменения состав отрядов рукокрылых и грызунов в связи с пересмотром их систематики. В предыдущих работах не было сведений об обитании в Бурятии восточноевропейской полевки, которая попала сюда, по-видимому, случайно с грузовым транспортом и успешно она проходит интродукцию [Моролдоев и др., 2017]. В результате видовой состав млекопитающих Бурятии увеличился более чем на 10 видов по сравнению с предыдущими данными.

Исчезло несколько видов. Дзерен Procapra gutturosa обитал до середины 20-го столетия [Леонтьев, 1949; Фетисов, 1949; Тимофеев, 1954]. Последняя встреча его датирована 1955 г. Ю.Г. Швецовым [Швецов, Смирнов, Монахов, 1984]. До 50-х годов в южных районах Бурятии (Кяхтинский район) дзерен был не редким, на него охотились. В 50-м году было решено закрыть на него охоту, так как он стал редким. До 70-годов недолго встречались в Бурятии три неудачно акклиматизированных вида заяц-русак Lepus europaeus, енотовидная собака Nyctereutes procyonioides, пятнистый олень Cervus nippon, которые не прижились. Этих видов в обновленный список не включили.

В ближайшее время есть вероятность потери обыкновенного бобра, представленного небольшой популяцией в Окинском районе. 
Довольно много видов в Бурятии представлены краевыми популяциями, большинство из них не распространены по всей территории республики. Это связано с историей формирования фауны и зональным экотонным положением региона.

Ниже в таблице 2 показана количественная характеристика систематического состава млекопитающих Бурятии.

Таблийа 2

Количественная характеристика систематического состава диких млекопитающих Бурятии

\begin{tabular}{|l|c|c|c|}
\hline \multirow{2}{*}{\multicolumn{1}{|c|}{ Отряды }} & \multicolumn{3}{c|}{ Количество, абс./\% } \\
\cline { 2 - 4 } & семейств & родов & видов \\
\hline Насекомоядные - Eulipotyphla & $3 / 14,3$ & $5 / 8,8$ & $12 / 12,9$ \\
\hline Рукокрылые - Chiroptera & $1 / 4,8$ & $5 / 8,8$ & $11 / 11,8$ \\
\hline Зайцеобразные - Lagomorpha & $2 / 9,5$ & $2 / 3,5$ & $5 / 5,4$ \\
\hline Грызуны - Rodentia & $6 / 28,6$ & $24 / 42,1$ & $38 / 40,9$ \\
\hline Хищные - Carnivora & $5 / 23,8$ & $13 / 22,8$ & $19 / 20,4$ \\
\hline Парнокопытные - Artiodactyla & $4 / 19,0$ & $8 / 14,0$ & $8 / 8,6$ \\
\hline Всего: & $21 / 100$ & $57 / 100$ & $93 / 100$ \\
\hline
\end{tabular}

Как видно, 40\% фауны составляют грызуны, одну пятую часть $(20,4 \%)$ представляют хищники. Чуть больше $10 \%$ соответственно насекомоядные и рукокрылые. Отряды зайцеобразных и парнокопытных представлены небольшой долей. На один род в среднем приходится 1,6 вида, в разных родах - от 1,0 до 8,0 видов. Наиболее богатыми оказались рода Sorex (8 видов), Myotis (6) и Mustella (5). У парнокопытных все рода представлены одним видом.

Зонально экотонное положение Бурятии повлияло на характер распространения многих видов. У 41 (44,1\%) вида границы ареалов проходят по Бурятии. Отмечено два эндемика - муйская полевка и байкальская нерпа.

\section{Литература}

1. Амгаланбаатар С., Доржиев Ц. З., Ридинг Р. Р. Структура ареала аргали Ovis ammon в Монголии и изменения ее в начале XXI в. // Вестник Бурятского государственного университета. Биология, география. 2014. Вып. 4(1). С. 58-66. Текст : непосредственный.

2. Амгаланбаатар С., Ридинг Р.П., Доржиев Ц.З. Динамика состояния популяций аргали (Ovis ammon) в Монголии (1975-2009 гг.) // Вестник Бурятского государственного университета. Биология, география. 2012. Вып. 4. С. 105-108. Текст : непосредственный.

3. Андронов Д. А. Встреча снежного барса Uncia uncia в Бичурском районе (Бурятия) // Байкальский зоологический журнал. 2012. № 1(9). С. 117. Текст : непосредственный.

4. Аристов А. А., Барышников Г. Ф. Млекопитающие фауны России и сопредельных территорий. Хищные и ластоногие. Санкт-Петербург, 2001.560 с. Текст : непосредственный.

5. Бадмаев Б. Б. Длиннохвостый суслик в условиях Западного Забайкалья. Новосибирск : Наука, 2007. 108 с. Текст : непосредственный.

6. Бадмаев Б. Б. Находка речного бобра, Castor fiber tuvinicus, в Восточных Саянах (Окинский райн Бурятии) // Зоол. журн. 1993. Т. 72, вып. 3. С. 152-153. Текст : непосредственный. 
7. Бадмаев Б. Б. Черношапочный сурок на севере Бурятии (распространение, кормовые растения и использование) // География и природные ресурсы. 2010. № 2. С. 81-84. Текст : непосредственный.

8. Банников А. Г. Млекопитающие Монгольской Народной Республики. Москва : Изд-во Академии наук СССР, 1954. 669 с. Текст : непосредственный.

9. Банникова А. А., Лебедева В. С. Отряд Насекомоядные Eulipotyphla // Млекопитающие России: систематико-географический справочник : сборник трудов Зоологического музея МГУ. Москва : Т-во научн. изданий КМК. Т. 52. С. 25-72. Текст : непосредственный.

10. Барышников Г. Ф., Тихонов А. Н. Млекопитающие фауны СССР и сопредельных территорий. Копытные. Ч. 1. Непарнопалые и Парнопалые (свиные, кабарговые, оленевые). Санкт-Петербург : Наука, 2009. 164 с. Текст : непосредственный.

11. Боескоров Г. Г. Систематика и происхождение современных лосей. Новосибирск : Наука, 2001. 120 с. Текст : непосредственный.

12. Борисова Н. Г., Старков А. И., Сазонов Г. И, Руднева Л. В. К экологии даурской пищухи в юго-западном Забайкалье // Фауна и экология млекопитающих Забайкалья / Тр. Зоологического ин-та РАН. Санкт-Петербург, 2001. Т. 288. С. 163-179. Текст : непосредственный.

13. Борисова Н. Г., Абрамов А. В., Старков А. И., Бороноева Г. И., Дагдунова А. А. Фауна млекопитающих Республики Бурятия // Фауна и экология млекопитающих Забайкалья / Тр. Зоологического ин-та РАН, 2001. Т. 288. С. 3-95. Текст : непосредственный.

14. Ботвинкин А. Д. Летучие мыши в Прибайкалье (биология, методы наблюдения, охрана). Иркутск: Время странствий, 2002. 208 с. Текст : непосредственный.

15. Ботвинкин А. Д., Осинцев А. В. Зимние и летние находки рукокрылых на Байкале и сопредельных территориях // Рукокрылые (Chiroptera) : материалы VI совещания по рукокрылым стран СНГ. Худжанд, 1995. С. 51-53. Текст : непосредственный.

16. Ботвинкин А. Д., Осинцев А. В., Морозов О. Н., Тиунов М. П. Зимовка рукокрылых в пещерной системе Долганская Яма (Западное Забайкалье) // Фауна и экология млекопитающих Забайкалья (Труды Зоологического института РАН). Санкт-Петербург, 2001. Т. 288). С. 154-163. Текст : непосредственный.

17. Булкина Т. М., Крускоп С. В. Поиск морфологических различий между генетически разнородными бурыми ушанами (Plecotus auritus s. lato, Vespertilionidae) // Plecotus et al. 2009. 11-12. С. 3-13. Текст : непосредственный.

18. Васильева И.А., Васильев А.Г., Большаков В.Н. Морфологическая дивергенция скальных полевок подрода Aschizomys (Rodentia, Cricetidae) // Зоологические исследования : сборник трудов Зоологического музея МГУ. Москва, 2008. С. 210-255. Текст : непосредственный.

19. Галкина Л. И. Новые находки амурского лемминга (Rodentia, Lemmus amurensis Vinogradov, 1924) // Систематика и экология животных. Новосибирск, 1980. С. 158-160. Текст : непосредственный.

20. Галкина Л.И. Структура населения мелких млекопитающих Витимского плоскогорья // Охотничье-промысловые ресурсы Сибири. Новосибирск : Наука. Сиб. отд-ние, 1986. С. 154-165. Текст : непосредственный.

21. Гептнер В. Г., Насимович А. А., Банников А. Г. Млекопитающие Советского Союза. Т. 1. Парнокопытные и непарнокопытные. Москва : Высшая школа. 1961. 776 с. Текст : непосредственный.

22. Голенищев Ф. Н., Войта Л. Л., Моролдоев И. В., Абрамсон Н. И., Петрова Т. В., Картавцева И. В. Новые находки муйской полевки (Rodentia: Cricetidae: Alexandromys mujanensis) в Забайкалье // Труды Зоологического института РАН. 2018. Т. 322, № 3. C. 357-384. Текст : непосредственный. 
23. Громов И.М., Баранова Г.И. (ред.) Каталог млекопитающих СССР (плиоцен современность). Ленинград : Наука, 1981. 456 с. Текст : непосредственный.

24. Громов И. М., Ербаева М. А. Млекопитающие России и сопредельных стран: Зайцеобразные и грызуны. Санкт-Петербург, 1995. 520 с. Текст : непосредственный.

25. Громов И. М., Поляков И. Я. Полевки (Microtinae). Фауна СССР. Млекопитающие. Т. 3, вып. 8. Ленинград : Наука, 1977. 504 с. Текст : непосредственный.

26. Гуреев А. А. Фауна СССР. Млекопитающие. Насекомоядные. Ленинград, 1979. Т. 4, вып. 2. 501 с. Текст : непосредственный.

27. Давыдов А. В., Холодова М. В., Марков Н. И., Мещерский И. Г., Груздев А. Р., Сипко Т. П., Царев С. А., Линьков А. Б., Рожков Ю. И. Генетическая изменчивость (мтДНК), расселение и дифференциация форм лося (Alces alces L.) // Молекулярно-генетические основы сохранения биоразнообразия млекопитающих Голарктики : материалы международной конференции. Москва : Т-во научн. изданий КМК, 2007. С. 45-48. Текст : непосредственный.

28. Дагдунова А. А., Бороноева Г. И. Структура населения мелких млекопитающих юга Витимского плоскогорья // Вестник Бурятского государственного университета. Биология. География. 2007. С. 225-216. Текст : непосредственный.

29. Демидович А. П. Териофауна окрестностей Байкальского целлюлозно-бумажного комбината // Научные труды ИГУ. Иркутск, 1988. С. 149-156. Текст : непосредственный.

30. Долгов В. А. Бурозубки Старого света. Москва, 1985.221 с. Текст : непосредственный.

31. Доржиев Ц. 3. Даурский еж в Западном Забайкалье // Редкие виды млекопитающих СССР и их охрана : материалы III Всесоюзного совещания. Москва : Наука, 1983. С. 39-40. Текст : непосредственный.

32. Доржиев Ц. З., Бадмаева Е. Н. Неворобьиные птицы Республики Бурятия: аннотированный список // Природа Внутренней Азии. The Nature of Inner Asia. 2016. № 1. С. 6-46. Текст : непосредственный.

33. Доржиев Ц. З., Калинина Л. Н., Цыренов А. В., Осодоев П. Н. Даурский еж в Западном Забайкалье // Ресурсы редких животных РСФСР, их охрана и воспроизводство : материалы к Красной книге. Москва, 1988. С. 87-89. Текст : непосредственный.

34. Доржиев Ц. 3., Носков В. Т. Современное состояние зайца-толая в Западном Забайкалье // Редкие виды млекопитающих СССР и их охрана : материалы III Всесоюзного совещания. Москва : Наука, 1983. С. 52-53. Текст : непосредственный.

35. Доржиев Ц. 3., Тулуев К. Д. Новые сведения о встрече красного волка в Восточном Саяне // Вестник Бурятского университета. Сер. 2. Биология. 2002. Вып. 2. С. 130. Текст : непосредственный.

36. Доржиев Ц. З., Хабаева Г. М., Богданова К. М., Бардонова Л. К., Боровицкая Г. К. Они нуждаются в охране. О редких и исчезающих видах фауны и флоры Бурятии. УланУдэ, 1985. 198 с. Текст : непосредственный.

37. Доржиев Ц. З., Хабаева Г. М., Юмов Б. О. Животный мир Бурятии (Состав и распределение наземных позвоночных). Иркутск, 1986. 123 с. Текст : непосредственный.

38. Доржиев Ц. 3., Цыбиков Ж. Б. Заход снежного барса на Джидинский хребет (Западное Забайкалье) // Вестник Бурятского университета. Сер. 2. Биология. 1999. Вып. 2. С. 138-139. Текст : непосредственный.

39. Доржиев Ц. З., Шаргаев М. А., Матурова Р. Т. К экологии корсака Юго-Западного Забайкалья // Экологические основы охраны и рационального использования хищных млекопитающих. Москва : Наука, 1979. С. 169-170. Текст : непосредственный.

40. Жаров В. Р. Материалы по численности и экологии черношапочного сурка в гольцовом поясе Баргузинского хребта // Экология наземных позвоночных животных Забайкалья : труды Баргузинского государственного заповедника. Улан-Удэ : Бурят. кн. изд-во, 1970. Вып. 6. С. 33-42. Текст : непосредственный. 
41. Зайцев М. В., Войта Л. Л., Шефтель Б. И. Млекопитающие фауны России и сопредельных территорий. Насекомоядные. Санкт-Петербург, 2014. 383 с. Текст : непосредственный.

42. Иванов Т. М. Тарбаган в верховьях р. Иркута // Известия Иркутского государственного научно-исследовательского противочумного института. Иркутск, 1950. Т. 8. С. 123-127. Текст : непосредственный.

43. Казаков Д. В. Новые данные по рукокрылым Баргузинского заповедника // Plecotus et. al. 2015. № 18. С. 54-59. Текст : непосредственный.

44. Казаков Д. В., Шумкина А. П., Ботвинкин А. Д., Морозов О. Н. Сибирский трубконос (Murina hilgendorfi Gray, 1842) в Прибайкалье: новые аспекты биологии // Известия Иркутского государственного университета. Сер. Биология. Экология, 2016. Т. 17. С. 63-75. Текст : непосредственный.

45. Калинина Л. Н., Нихилеева Т. П. К экологии китайской полевки Lasiopodomys mandarinus в Юго-Западном Забайкалье // Экосистемы Южного Забайкалья: история изучения, оценка и проблемы сохранения биоразнообразия : материалы научно-практической конференции, посвященной 100-летию работ кяхтинского краеведа, натуралиста и препаратора Владислава Степановича Моллесона (1853-1899) (22-23 октября 1998 г.). Улан-Удэ, 1998. С. 61-64. Текст : непосредственный.

46. Калинина Л. Н., Нихилеева Т. П. Некоторые особенности экологии китайской полевки в Юго-Западном Забайкалье // Биологические ресурсы и ведение государственных кадастров Бурятской АССР : материалы научной конференции. Улан-Удэ, 1991. С. 77-78. Текст : непосредственный.

47. Картавцева И. В., Васильева Т. В., Шереметьева И. Н., Лемская Н. А., Моролдоев И. В., Голенищев Ф. Н. Генетическая изменчивость трех изолированных популяций муйской полевки Alexandromys mujanensis Orlov et Kovalskaja, 1978 (Rodentia, Arvicolinae) // Генетика. 2019. Т. 55, № 8. С. 920-935. Текст : непосредственный.

48. Каталог млекопитающих СССР. Плиоцен - современность / Г. Ф. Барышников, В. Е. Гарутт, И. М. Громов [и др.]. Ленинград, 1981. 456 с. Текст : непосредственный.

49. Козулин В. М., Моролдоев И. В., Дарижапов Е. А., Ананин А. А. Многолетняя динамика черношапочного сурка Marmota camtschatica doppelmayeri на западном макросклоне Баргузинского хребта // Известия Иркутского государственного университета. Сер. Биология. Экология. 2016. Т. 18. С. 27-35. Текст : непосредственный.

50. Крускоп С. В. Отряд Chiroptera / отв. ред. И. Я. Павлинов, А. А. Лисовский // Млекопитающие России : систематико-географический справочник (Сборник трудов Зоологического музея МГУ). Москва : Т-во научн. изданий КМК. 2012. Т. 52. С. 73-126. Текст : непосредственный.

51. Крускоп С. В., Борисенко А. В., Иванова Н. В., Лим Б. К., Игер Дж. Л. Использование ДНК-штрихкодов для выявления филогеографических разрывов среди рукокрылых Восточной Палеарктики // Молекулярно-генетические основы сохранения биоразнообразия млекопитающих Голарктики : материалы международной конференции. Москва : Т-во научн. изданий КМК, 2007. С. 115-121. Текст : непосредственный.

52. Кузнецова М.В. Молекулярные исследования и проблемы классификации Cervus elaphus // Молекулярно-генетические основы сохранения биоразнообразия млекопитающих Голарктики : материалы международной конференции. Москва : Т-во научн. изданий КМК, 2007. С. 128-134. Текст : непосредственный.

53. Лебедев В. С., Лисовский А. А. Географическая изменчивость метрических признаков черепа и таксономическая структура хомячков Cricetulus группы barabensis (Rodentia, Cricetidae) // Зоологический журнал. 2008. № 87(3). С. 361-374. Текст : непосредственный. 
54. Лисовский А. А. Распространение северной (Ochotona hyperborean) и алтайской (O. alpine) пищух // VI Съезд териологического об-ва : тезисы докладов. Москва, 1999. C. 139. Текст : непосредственный.

55. Литвинов Н. И. Некоторые особенности териофауны южной части Байкальской котловины // Зоологические исследования в Восточной Сибири : сборник научных трудов. Иркутск : Изд-во ИСХИ, 1992. С. 35-45. Текст : непосредственный.

56. Литвинов Н. И. Фауна островов Байкала (наземные позвоночные животные). Иркутск, 1982. 132 с. Текст : непосредственный.

57. Литвинов Н. И., Базардорж Д. Млекопитающие Прихубсугулья. Монгольская Народная Республика. Иркутск: Изд-во Иркутского ун-та, 1992. 136 с. Текст : непосредственный.

58. Литвинов Н. И., Васильев Г. И., Ельшанская Н. И. Грызуны Тункинской долины, Прихубсугулья и их эктопаразиты // Экология охотничьих зверей и птиц, технология производства в охотничьем хозяйстве. Иркутск, 1976. С. 23-30. Текст : непосредственный.

59. Литвинов Н. И., Тарасов М. П. Монгольский сурок в Прибайкалье // Охота и охотничье хозяйство. 1966. № 2. С. 21. Текст : непосредственный.

60. Литвинов Н. И., Тарасов М. П., Швецов Ю. Г. Материалы по фауне наземных позвоночных Тункинской и Мондинской котловин // Изв. Вост.-Сиб. отд. Геогр. об-ва СССР. 1969. Т. 66. С. 65-69. Текст : непосредственный.

61. Лямкин В. Ф. Аннотированный список наземных млекопитающих (Mammalia) котловины озера Байкал // Аннотированный список фауны озера Байкал и его водосборного бассейна. Т. 1. Озеро Байкал. Новосибирск, 2001. С. 176-250. Текст : непосредственный.

62. Лямкин В. Ф. Видовая структура и распределение населения мелких млекопитающих в северной части котловины озера Байкал // Биогеографические исследования в бассейне озера Байкал. Иркутск, 1986. С. 54-69. Текст : непосредственный.

63. Лямкин В. Ф. Зоогеография млекопитающих и птиц Баргузинской котловины // Региональные биогеографические исследования в Сибири. Иркутск, 1977. С. 111-177. Текст : непосредственный.

64. Лямкин В. Ф. Крошечная бурозубка (Sorex minutissimus Zimm.) в условиях Северного Прибайкалья и Забайкалья // Вопросы биогеографии юга Восточной Сибири. Иркутск, 1988. С. 69-93. Текст : непосредственный.

65. Лямкин В. Ф. Особенности населения мелких млекопитающих южной оконечности Байкальского хребта // Экология позвоночных животных Восточной Сибири. Иркутск : Изд-во Иркут. ун-та, 1983. С. 186-201. Текст : непосредственный.

66. Лямкин В. Ф. Экология и зоогеография млекопитающих межгорных котловин Байкальской рифтовой зоны. Иркутск: Изд-во Ин-та географии СО РАН, 2002. 133 с. Текст : непосредственный.

67. Лямкин В. Ф., Малышев Ю. С. Материалы к экологии муйской полевки // Фауна и ресурсы позвоночных бассейна оз. Байкал. Улан-Удэ, 1980. С. 70-75. Текст : непосредственный.

68. Лямкин В. Ф., Пузанов В. М., Малышев Ю. С. Муйская полевка (Microtus mujanensis Orl. et Kov.) - особенности ареала и некоторые вопросы экологии популяции // Экология позвоночных животных Восточной Сибири. Иркутск : Изд-во Иркутского ун-та, 1983. С. 167-186. Текст : непосредственный.

69. Лямкин В. Ф., Пузанов В. М., Малышев Ю. С. Особенности пространственной структуры сообществ мелких млекопитающих Муйской котловины (Северо-Восточное Забайкалье) // Распространение и экология млекопитающих Якутии. Якутск : Изд-во ЯФ СО АН СССР, 1982. С. 39-47. Текст : непосредственный.

70. Малыгин В. М., Старцев Н. В., Зима Я. Кариотипы и распространение хомячков из группы barabensis (Rodentia, Cricetidae) // Вестник Московского университета. Cep. 16. Биология. 1992. № 2. С. 32-39. Текст : непосредственный. 
71. Матурова Р. Т. Мелкие млекопитающие хребта Улан-Бургасы (Восточное Прибайкалье). Новосибирск : Наука, 1982. 103 с. Текст : непосредственный.

72. Матурова Р. Т., Доржиев Ц. З., Иванова Г. И. Грызуны и зайцеобразные западной части Заганского хребта и Тугнуйской котловины // Насекомые и позвоночные Забайкалья. Улан-Удэ, 1977. С. 83-10. Текст : непосредственный.

73. Медведев Д. Г. Историческое и современное распространение ирбиса и его жертв в Восточной Сибири // Труды Байкало-Ленского гос. прир. заповедн. Москва : Инкомбук, 1998. Вып. 1. С. 120-123. Текст : непосредственный.

74. Медведев Д. Г. История открытия и изучения снежного барса Uncia uncia (Schreber, 1776) в Иркутской области // Байкальский зоологический журнал. 2012. № 1(9). С. 102-104. Текст : непосредственный.

75. Медведев Д. Г. Красный волк на северной периферии ареала (Сибирь и Дальний Восток) // Зоологические исследования в Восточной Сибири. Иркутск : Изд-во ИСХИ, 1993. С. 60-64. Текст : непосредственный.

76. Медведев Д. Г. Манул на Восточном Саяне и в Тункинской долине // Бюллетень ВСНЦ СО РАМН. 2007. Т. 2(56). С. 93-96. Текст : непосредственный.

77. Медведев Д. Г. Сибирский горный козел Восточного Саяна // Национальному парку «Тункинский» - 10 лет. Улан-Удэ, 2001. С. 75-79. Текст : непосредственный.

78. Медведев Д. Г. Снежный барс в горах Восточного Саяна // Снежный барс : сборник докладов VI Международного симпозиума по снежному барсу. Алма-Ата : Кайнар, 1992. С. 80-90. Текст : непосредственный.

79. Медведев Д. Г. Снежный барс, или ирбис Uncia uncial Schreber, 1776 // Красная книга Республики Бурятия. Редкие и находящиеся под угрозой исчезновения виды животных, растений и грибов. Изд-е 3-е, перераб. и доп. Улан-Удэ: Изд-во БНЦ СО РАН, 2013. С. 246-247. Текст : непосредственный.

80. Медведев Д. Г., Бадмаев Б. Б. Красный волк // Красная книга Республики Бурятия. Изд. 3-е, перераб. и доп. Улан-Удэ: Изд-во БНЦ СО РАН. 2013. С. 242. Текст : непосредственный.

81. Млекопитающие России: список видов и прикладные аспекты» / А. А. Лисовский, Б. И. Шефтель, А. П. Савельев [и др.]. Москва, 2019. 191 с. Текст : непосредственный.

82. Млекопитающие России : систематико-географический справочник / отв. ред. И. Я. Павлинов, А. А. Лисовский. Москва : Т-во научн. изданий КМК. 2012. 604 с. Текст : непосредственный.

83. Млекопитающие фауны СССР / И. М. Громов, А. А. Гуреев, Г. А. Новиков [и др.]. Москва; Ленинград, 1963. Ч. 1. 638 с. Текст : непосредственный.

84. Монахов Г. И., Бакеев Н. Н. Соболь. Москва : Лесная промышленность, 1981. 240 с. Текст : непосредственный.

85. Моролдоев И. В, Шереметьева И.Н., Картавцева И.В. Первая находка восточноевропейской полёвки (Microtus rossiaemeridionalis) в Бурятии // Российский журн. биологических инвазий. 2017. № 2. С. 88-94. Текст : непосредственный.

86. Орлов В. Н., Исхакова Э. Н. Таксономия надвида Cricetulus barabensis (Rodentia, Cricetidae) // Зоол. журн. 1975. Т. 54, № 4. С. 597-604. Текст : непосредственный.

87. Орлов В. Н., Ковальская Ю. М. Microtus mujanensis sp. n. (Rodentia, Cricetidae) из бассейна реки Витим // Зоологический журнал. 1978. Т. 57, вып. 8. С. 1224-1232. Текст : непосредственный.

88. Орлов В. Н., Ковальская Ю. М. Новый вид серых полевок Microtus mujanensis (Rodentia, Cricetidae) из бассейна р. Витим (Забайкалье) // Систематика и цитогенетика млекопитающих. Москва : Наука, 1975. С. 32. Текст : непосредственный. 
89. Павлинов И. Я. Систематика современных млекопитающих // Сборник трудов Зоологического музея МГУ. 2003. № 46. С. 3-297. Текст : непосредственный.

90. Пастухов В. Д. Нерпа Байкала: биологические основы рационального использования и охрана ресурсов. Новосибирск : Наука, Сибирское отд-ние, 1993. 271 с. Текст : непосредственный.

91. Подаревский В. Б. Проблемы охотохозяйственной акклиматизации в Восточной Сибири. Иркутск, 1936. 119 с. Текст : непосредственный.

92. Поплавская Н. С., Лебедев В. С., Банникова А. А, Малыгин В. М., Суров А. В. Внутрипопуляционная изменчивость кариотипов хомячков группы «barabensis» (Cricetidae, Rodentia) из Центральной Монголии и возможные причины ее возникновения // Доклады Академии наук. Сер. биологическая, 2011. № 439(1). С. 139-141. Текст : непосредственный.

93. Попов В. В. Матвеев А. Н. Охрана позвоночных животных в Байкальском регионе. Иркутск, 2006. 110 с. Текст : непосредственный.

94. Попов В. В. Млекопитающие Иркутской области (аннотированный список) // Байкальский зоологический журнал. 2011. № 1 (6). С. 69-78. Текст : непосредственный.

95. Попов В. В., Гулгонов В. Е., Китаев А. В. Конспект фауны наземных позвоночных Тункинского национального парка. Иркутск: Изд-во Байкальского госуниверситета, 2017. 106 с. Текст : непосредственный.

96. Реймерс Н. Ф. Птицы и млекопитающие южной тайги Средней Сибири. Москва ; Ленинград, 1966. 418 с. Текст : непосредственный.

97. Рожков Ю. И., Проняев А. В., Давыдов А. В., Холодова М. В., Сипко Т. П. Лось: популяционная биология и микроэволюция. Москва: Т-во научных изданий КМК, 2009. 520 с. Текст : непосредственный.

98. Скалон В. Н. Материалы к познанию фауны южных границ Сибири // Изв. Гос. противочумного ин-та Сибири и Дальнего Востока. Москва ; Иркутск, 1936. С. 135-210. Текст : непосредственный.

99. Скалон В. С., Шаргаев М. А. Млекопитающие Прибайкалья (общий инвентаризационный список) // Насекомые и позвоночные Забайкалья: тр. Бурятского ин-та естественных наук БФ СО АН СССР. Улан-Удэ, 1977. Вып. 21. С. 67-73. Текст : непосредственный.

100. Смирнов М. Н. Красный волк // Красная книга Бурятской АССР. Улан-Удэ, 1988. С. 37-39. Текст : непосредственный.

101. Смирнов М. Н. Косуля в Западном Забайкалье. Новосибирск : Наука, Сиб. отд-ние, 1978. 189 с. Текст : непосредственный.

102. Сморчакова А. В. К распространению и экологии китайской полевки Lasiopodomys mandarinus в Бурятии // Труды ЗИН РАН, 2001. Т. 288. С. 188-204. Текст : непосредственный.

103. Соколов В. Е., Орлов В. Н. Определитель млекопитающих Монгольской Народной Республики. Москва : Наука, 1980. 350 с. Текст : непосредственный.

104. Стрелков П. П., Бунтова Е. Г. Усатая ночница (Myotis mystacinus) и ночница Брандта (Myotis brandti) в СССР и взаимоотношения этих видов. Сообщение $1 / /$ Зоол. журн., 1982. Т. 61, вып. 8. С. 1227-1241. Текст : непосредственный.

105. Стрелков П. П. Бурый (Plecotus auritus) и серый (P. austriacus) ушаны (Chiroptera,Vespertilionidae) в СССР. Сообщение 1 // Зоологический журнал. 1988. № 67(1). С. 90-101. Текст : непосредственный.

106. Ступина А. Г. Грызуны долины р. Верхняя Ангара // Краеведческий сборник Бурятского филиала ВГО. Улан-Удэ, 1961. Вып. 6. С. 108-113. Текст : непосредственный.

107. Тиунов М. П. Рукокрылые Дальнего Востока России. Владивосток : Дальнаука, 1997. 135 с. Текст : непосредственный.

108. Туманов И. Л. Редкие хищные млекопитающие России (мелкие и средние виды). Санкт-Петербург : Бранко, 2009. 448 с. Текст : непосредственный. 
109. Туров С. С. Материалы по млекопитающим северо-восточного побережья Байкала и Баргузинского хребта // Сб. тр. Гос. зоол. музея МГУ. Москва, 1936. Вып. 3. С. 26. Текст : непосредственный.

110. Устинов С. К. Распространение и стациальное распределение кабарги на Баргузинском хребте // Тр. Баргузинского заповедника. Улан-Удэ, 1961. Вып. 2. С. 75-80. Текст : непосредственный.

111.Фетисов А. С. Стациальное распределение и относительная численность мышевидных грызунов в лесостепной полосе южной оконечности Западного Забайкалья // Известия биол.-геогр. научно-исслед. ин-та при Иркутск. ун-те. 1942. Т. 9, вып. 3-4. С. 73-103. Текст : непосредственный.

112. Фетисов А. С. К распространению и экологии полевки Виноградова в Восточной Сибири // Докл. АН СССР. 1955. Т. 104, вып. 2. С. 326-328. Текст : непосредственный.

113. Фетисов А. С. Материалы по систематике и географии млекопитающих Западного Забайкалья // Известия Иркутского научно-исследовательского ин-та Сибири и Дальнего Востока, 1936. № 3. С. 86-119. Текст : непосредственный.

114. Фетисов А. С. Новый подвид полевки из Восточной Сибири // Труды Зоол. музея МГУ. 1941. Вып. 6. С. 75-76. Текст : непосредственный.

115. Фетисов А. С. Обзор млекопитающих Кяхтинского аймака Бурят-Монголии // Труды Кяхтинского краевед. музея и Кяхтинского отд-ния Всесоюз. Географич. об-ва. Улан-Удэ, 1949. Т. 16, вып. 1. С. 119-127. Текст : непосредственный.

116. Фетисов А. С. О млекопитающих долины р. Уды // Труды Иркутского университета, 1953. Т. 7, вып. 1-2. С. 29-38. Текст : непосредственный.

117. Филонов К. П. Дополнение к списку млекопитающих Баргузинского заповедника // Труды Баргузинского заповедника. Улан-Удэ, 1962. Вып. 4. С. 228-229. Текст : непосредственный.

118. Флинт В. Е. О биологии длиннохвостого хомячка // Зоологический журнал. 1966. Т. 45, вып. 3. С. 471-474. Текст : непосредственный.

119. Черникин Е. М. Экология соболя (Martes zibellina L. 1758) в Баргузинском заповеднике. Улан-Удэ: Изд-во Бурятского госуниверситета, 2006. 266 с. Текст : непосредственный.

120. Шаргаев М. А., Матурова Р. Т., Доржиев Ц. З. Вопросы экологии и охраны манула в Бурятии // Экологические основы охраны и рационального использования хищных млекопитающих. Москва : Наука, 1979. С. 123. Текст : непосредственный.

121. Швецов Ю. Г., Литвинов Н. И. Млекопитающие бассейна р. Нижний Кочергат (юго-восточное Прибайкалье) // Изв. Иркут. СХИ. 1967. Вып. 25. С. 209-223. Текст : непосредственный.

122. Швецов Ю. Г. Мелкие млекопитающие Байкальской котловины. Новосибирск : Наука, 1977. 159 с. Текст : непосредственный.

123. Швецов Ю. Г. Тарбаган в Юго-Западном Забайкалье // Сурки, распространение и экология. Москва : Наука, 1978. С. 154-163. Текст : непосредственный.

124. Швецов Ю. Г., Смирнов М. Н., Монахов Г. И. Млекопитающие бассейна озера Байкал. Новосибирск : Наука, 1984. 358 с. Текст : непосредственный.

125. Юдин Б. С. Фауна насекомоядных млекопитающих (Mammalia, Insectivora) Предбайкалья и Забайкалья // Труды Биол. ин-та СО РАН. 1973. Вып. 16. С. 280-296. Текст : непосредственный.

126. Юдин Б. С. Насекомоядные млекопитающие Сибири. Новосибирск : Наука. Сибирское отд-ние, 1989. 360 с. Текст : непосредственный.

127. Юдин Б. С., Галкина Л. И., Потапкина А. Ф. Млекопитающие Алтае-Саянской горной страны. Новосибирск : Наука, 1979. 296 с. Текст : непосредственный.

128. Benda P., Tsytsulina K. A. Naxonomic Revision of Myotis mystacinus Grup (Mammalia: Chiroptera) in the Western Palaearctic // Acta Soc. Zool. Bohem. 2000. V. 64. P. 331-398. 
129. Horaček I., Hanak V. Comments on the systematics and phylogeny of Myotis nattereri (Kuhl, 1818) // Myotis, 1984. No. 21-22. P. 20-29.

130. Kruskop S. V. Towards the taxonomy of the Russian Murina (Vespertilionidae, Chiroptera) // Russian J. of Theriology. 2005. V. 4. No. 2. P. 91-99.

131. Kruskop S. V., Borisenko A. V., Ivanova N. V., Lim B. K., Eger J. L. Genetic diversity of Northeastern Palaearctic bats as revealed by DNA barcodes // Acta Chiropterologica. 2012. V. 14. No. 1. P. 1-14. DOI: 10.3161/150811012X654222

132. Ludta C. J., Schroeder W., Rottmann O., Kuehn R. Mitochondrial DNA phylogeography of red deer (Cervus elaphus) // Molecular Phylogenetics and Evolution. 2004. No. 31 (3). P. 1064-1083.

133. Matveev V. A., Kruskop S. V., Kramerov D. A. Revalidation of Myotis petax Hollister, 1912 and its new status in connection with M. daubentonii (Kuhl, 1817) (Vespertilionidae, Chiroptera) // Acta Chiropterologica. 2005. V. 7. No. 1. P. 23-37.

134. Meiri M., Kosintsev P., Conroy K., Meiri S., Barnes I., Lister A. Subspecies dynamics in space and time: A study of the red deer complex using ancient and modern DNA and morphology // Journal of Biogeography. 2018. No. 45(2). P. 367-380.

135. Reiter A., Benda P. New Records of Bats in the Baikal Region // European Bat Research Symposium (Evora, Portugal, 22-27 August, 1993) : Abstract Book. Evora, Portugal, 1993. P. 43.

136. Shenbrot G.I., Krasnov B.R. An atlas of the geographic distribution of the arvicoline rodents of the World (Rodentia, Muridae: Arvicolinae). Sofia: Pensoft, 2005. 336 p.

137. Spitzenberger F. A., Strelkov P. P., Winkler H., Haring E. A preliminary revision of the genus Plecotus (Chiroptera, Vespertilionidae) based on genetic and morphological results // Zoologica Scripta. 2006. V. 35. Iss. 3. P. 187-230. DOI: 10.1111/j.1463-6409.2006.00224.x

138. Tsytsulina K.A., Dick M.H., Maeda K., Masuda R. Systematics and phylogeography of the steppe whiskered bat Myotis aurascens Kuzyakin, 1935 (Chiroptera, Vespertilionidae) // Russian Journal of Theriology. 2012. V. 11. N 1. P. 1-20. Doi: 10.15298/rusjtheriol.11.1.01

139. Zhang Y., Jin S., Quan G., Li S., Ye Z., Wang F., Zhang M. Distribution of mammalian species in China. Beijing : China Forestry Publ., 1997. 280 p.

Статья поступила в редакциию 24.10.2020; одобрена после рецензирования 03.11.2021; принята к публикащии 20.12.2021.

\section{MAMMALS OF BURYATIA: TAXONOMIC COMPOSITION AND TERRITORIAL PLACEMENT}

Ts. Z. Dorzhiev

Tsydypzhap Z. Dorzhiev

Dr. Sci. (Biol.), Prof.,

Dorzhi Banzarov Buryat State University

24a Smolina St., Ulan-Ude 670000, Russia

Institute of General and Experimental Biology SB RAS

6 Sakhyanovoy St., Ulan-Ude 670037, Russia

tsydypdor@mail.ru

Abstract. On the basis of the literature and own data, an updated annotated list of mammals of Buryatia, that registered on the territory of the republic in the last 50 years is given. The species noted before the 70-s of the last century and then disappeared (Lepus europaeus, Nyctereutes procyonioides, Japanese worm, Procapra gutturosa) were not included in the list. 
Species from adjacent territories that clearly do not live in the republic are also excluded. The composition of the bat and rodent orders has undergone noticeable changes due to the revision of their taxonomy. As a result, the species composition of mammals in Buryatia increased by more than 10 species compared to previous data. Currently, the theriofauna of the republic has 93 species belonging to 6 orders, 21 families and 57 genera. The order of Eulipotyphla includes 12 species, Chiroptera - 11, Lagomorpha - 5, Rodentia - 35, Carnivora - 19 and Artiodactyla - 7. The names of the species are given according to new reports, but in order to avoid confusion, the former names are also given. The features of the habitats of all species, the nature of their distribution and biotopic distribution in Buryatia are described. New places of finds of some forms on the territory of the republic have been clarified and indicated. A significant proportion (27\%) of species that located on the border of the range in Buryatia is shown. For Chiroptera, the nature of stay and wintering sites are marked.

Keywords: mammals, taxonomic composition, habitat, biotopic placement, Buryatia, Baikal region.

Acknowledgments. The research was partly supported by a grant for innovative scientific research of Dorzhi Banzarov Buryat State University in 2021 (№ 21-06-0502).

For citation

Dorzhiev Ts. Z. Mammals of Buryatia: Taxonomic Composition and Territorial Placement. Nature of Inner Asia. 2021; 4(19): 7-44 (In Russ.). DOI: 10.18101/2542-0623-2021-4-7-44

The article was submitted 24.10.2021; approved after reviewing 03.11.2021; accepted for publication 20.12.2021. 